\title{
Freshwater Flux and Spatiotemporal Simulated Runoff Variability into Ilulissat Icefjord, West Greenland, Linked to Salinity and Temperature Observations near Tidewater Glacier Margins Obtained Using Instrumented Ringed Seals
}

\author{
Sebastian H. Mernild, ${ }^{*,+}$ David M. Holland,,${ }^{\#}$ Denise Holland, ${ }^{@}$ AqQAlu Rosing-Asvid, ${ }^{\text {\& }}$ \\ JACOB C. YDE, ${ }^{* *}$ GLEN E. LISTON, ${ }^{++}$AND KONRAD STEFFEN ${ }^{\# \#, @ @, \& \& ~}$ \\ * Glaciology and Climate Change Laboratory, Center for Scientific Studies/Centro de Estudios Cientificos, Valdivia, Chile \\ ${ }^{+}$Climate, Ocean, Sea Ice Modeling Group, Computational Physics and Methods, Los Alamos National \\ Laboratory, Los Alamos, New Mexico \\ ${ }^{*}$ Courant Institute of Mathematical Sciences, New York University, New York, New York \\ ${ }^{\circledR}$ Center for Global Sea Level Change, New York University Abu Dhabi, Abu Dhabi, United Arab Emirates \\ ${ }^{\&}$ Greenland Institute of Natural Resources, Nuuk, Greenland \\ ** Sogn og Fjordane University College, Sogndal, Norway \\ ${ }^{++}$Cooperative Institute for Research in the Atmosphere, Colorado State University, Fort Collins, Colorado \\ \#\# Swiss Federal Research Institute WSL, Birmensdorf, Switzerland \\ ${ }^{\circledR @}$ Institute for Atmosphere and Climate, Swiss Federal Institute of Technology, Zurich, Switzerland \\ ${ }^{\& \&}$ Architecture, Civil and Environmental Engineering, Ecole Polytechnique Federal de Lausanne, Lausanne, Switzerland
}

(Manuscript received 23 October 2014, in final form 3 February 2015)

\begin{abstract}
The distribution of terrestrial surface runoff to Ilulissat Icefjord, west Greenland, is simulated for the period 2009-13 to better emphasize the spatiotemporal variability in freshwater flux and the link between runoff spikes and observed hydrographic conditions at the Greenland Ice Sheet tidewater glacier margins. Runoff model simulations were forced with automatic weather station data and verified against snow water equivalent depth, equilibrium line altitude, and quasi-continuous salinity and temperature observations obtained by ringed seals. Instrumented seals provide a novel platform to examine the otherwise inaccessible waters beneath the dense ice mélange within the first $0-10 \mathrm{~km}$ of the calving front. The estimated mean freshwater flux from land was $70.6 \pm 4.2 \mathrm{~km}^{3} \mathrm{yr}^{-1}$, with an $85 \%$ contribution of ice discharge from Jakobshavn Isbrae (also known as Sermeq Kujalleq), 14\% from runoff, and the remaining $1 \%$ from precipitation on the fjord surface area, subglacial geothermal melting, and frictional melting due to basal ice motion. Runoff was simulated to be present from May to November and to vary spatially according to glacier cover and individual catchment size. Salinity and temperature observations correlate (significantly) with simulated runoff for the upper part of both the main fjord and southern fjord arm. Also, at the tidewater glacier margins in the northern and southern arm of Ilulissat Icefjord, salinity changes in the upper water column (upper $50 \mathrm{~m}$ ) are significant after temporal spikes in runoff during late summer, while small-amplitude runoff variability during the recession of runoff did not create a clear signal in observed salinity variability. Also, in the southern arm near the glacier margin (between 100- and 150-m depth), the heterogeneous distribution in salinity could be because of the mixing of meltwater going upward from passing the grounding line. The effect of runoff spikes on observed salinity is less pronounced near the ice margin of Jakobshavn Isbrae than in the north and south arms.
\end{abstract}

\section{Introduction}

Freshwater runoff from the Greenland Ice Sheet (GrIS) has increased on average since 1960 (Mernild et al. 2011a; Mernild and Liston 2012; Bamber et al.

\footnotetext{
Corresponding author address: Dr. Sebastian H. Mernild, Glaciology and Climate Change Laboratory, Center for Scientific Studies/Centro de Estudios Cientificos, Avenida Arturo Prat 514, 5110466 Valdivia, Chile. E-mail: smernild@gmail.com
}

2012). Atmospheric warming explained approximately half of the contemporary mass loss of the GrIS up to 2005 (Enderlin et al. 2014), where the other half was due to the calving of icebergs. The contribution from the calving of icebergs to mass loss has accelerated in recent decades because of the rapid retreat, ice speedup, and dynamic thinning of outlet glaciers from the GrIS (van den Broeke et al. 2009; Straneo et al. 2013). For the period 2009-12, however, the relative contribution of the calving of icebergs decreased to approximately one-third 
because of an increase in surface runoff (Enderlin et al. 2014). Freshwater fluxes from Greenland exert an important influence on the circulation and stratification of adjacent fjords and oceans, including the Atlantic meridional overturning circulation (Rahmstorf et al. 2005; Straneo et al. 2011; Weijer et al. 2012). At present, there is limited quantitative information about the spatial and temporal patterns of drainage basins and associated ice discharge and runoff fluxes from Greenland. Continuous river runoff observations have been recorded at only a few watersheds for more than a few years (e.g., Mernild and Hasholt 2006; Hasholt et al. 2008; Mernild et al. 2008a,b; Mikkelsen et al. 2013; Rennermalm et al. 2013); these river runoff observations transfer less than $1 \%$ of the total Greenland runoff to the adjacent seas (Mernild and Liston 2012).

Recently, satellite-derived glacier area and surface velocity measurements have shown retreat of calving fronts and acceleration of marine-terminating glaciers in most sectors of the GrIS (e.g., Joughin et al. 2010, 2014; Box and Decker 2011; Howat and Eddy 2011). In particular, variations in ice discharge and increasing mass loss have been observed recently at four of Greenland's largest ice streams: Jakobshavn Isbrae (also referred to as Sermeq Kujalleq), Helheim, Kangerdlugssuaq, and the northeast Greenland ice stream (Luckman et al. 2006; Howat et al. 2007, 2011; van den Broeke et al. 2009; Joughin et al. 2012; Khan et al. 2014). The processes driving these changes are still poorly understood (Straneo et al.2012). However, one leading hypothesis is that it is caused by increased submarine melting at the glacier terminus, leading to thinning and ungrounding of the floating ice tongue and reduction in the frontal buttressing to glacier flow (Thomas 2004; Holland et al. 2008; Motyka et al. 2011; Straneo et al. 2012). In the case of Jakobshavn Isbrae, it appears that the area reduction and ice speedup were initiated by a switch to higher ocean temperatures along the west Greenland coast and estuaries in the late 1990s (Holland et al. 2008; Hansen et al. 2012; Rignot et al. 2012) and to some extent by changes in climate (e.g., van den Broeke et al. 2009; Hanna et al. 2009, 2013a).

At Jakobshavn Isbrae, iceberg calving is thought to be responsible for most of the freshwater flux at the terminus (Gladish et al. 2015), while runoff only constitutes a minor proportion. Intense calving in the narrow fjord creates the dense surface cover know as ice mélange, and melting of the icebergs (and probably seasonal melting of sea ice cover during late spring and early summer) lowers the salinity of the nearby water of the upper layers of the fjord (Amundson et al. 2010; Straneo et al. 2011, 2013). Besides being less dense, the waters are also somewhat cooler. Waters below about 300-m depth in the fjord have properties matching those of waters at intermediate depths about $200-400 \mathrm{~m}$ in Disko Bay but also temperatures that are generally quite homogeneous with variations less than $1.0^{\circ} \mathrm{C}$ (Gladish et al. 2015). In this study, detailed analyses were performed of the amount of freshwater flux from ice discharge, subglacial geothermal melting, frictional melting due to basal ice motion, precipitation falling on the fjord surface, and from the spatial distribution of simulated runoff from individual catchments feeding Ilulissat Icefjord (also referred to as Ilulissat Kangia or Ilulissat Isfjord). These analyses were designed to improve our understanding of 1) both the annual and seasonal variability in freshwater fluxes throughout the simulation period; 2) the spatial and seasonal distribution of freshwater runoff to the fjord; 3 ) the ratio between runoff and ice discharge from the Jakobshavn Isbrae catchment; and 4) the link between the seasonal runoff distribution and observed hydrographic conditions in the Ilulissat Icefjord, including near the glacierocean boundary at the GrIS tidewater glacier margins. The latter point is achieved by using ringed seals fitted with instrumentation for temperature, pressure, and salinity observations beneath the ice mélange. This method allows for the collection of a unique dataset of hydrographic profiles in the Ilulissat Icefjord and within the ice mélange zone $0-10 \mathrm{~km}$ from the calving front. In addition, this study introduces modeling tools capable of assessing connections between variations in the spatial distribution of runoff, changes in the observed temperature and salinity profiles near the margin of tidewater glaciers, and the subaqueous vertical distribution of runoff draining from the glacier margin. The impact on the temperature and salinity conditions in the Ilulissat Icefjord and near the margin of the tidewater glaciers from the spatial and temporal distributions of runoff represents a critical link between terrestrial and estuary processes at glacier-ocean boundaries.

This study examines and improves upon our quantitative understanding of the GrIS surface mass balance (SMB) conditions (the accumulation and ablation processes) and subsequently the terrestrial spatiotemporal distribution of runoff draining into the entire Ilulissat Icefjord (including the northern and southern fjord arms) from both the GrIS and the proglacial landscape for a 5-yr period from 2009 to 2013. As part of this study, the coupled SnowModel/HydroFlow modeling system (Liston and Elder 2006a; Liston and Mernild 2012; Mernild and Liston 2012) was used to estimate runoff draining into the fjord. The simulated spatial and seasonal variability in runoff were then related to salinity and temperature observations from water conductivity-temperature-depth (CTD) Satellite Relay Data Logger (SRDL) instruments 

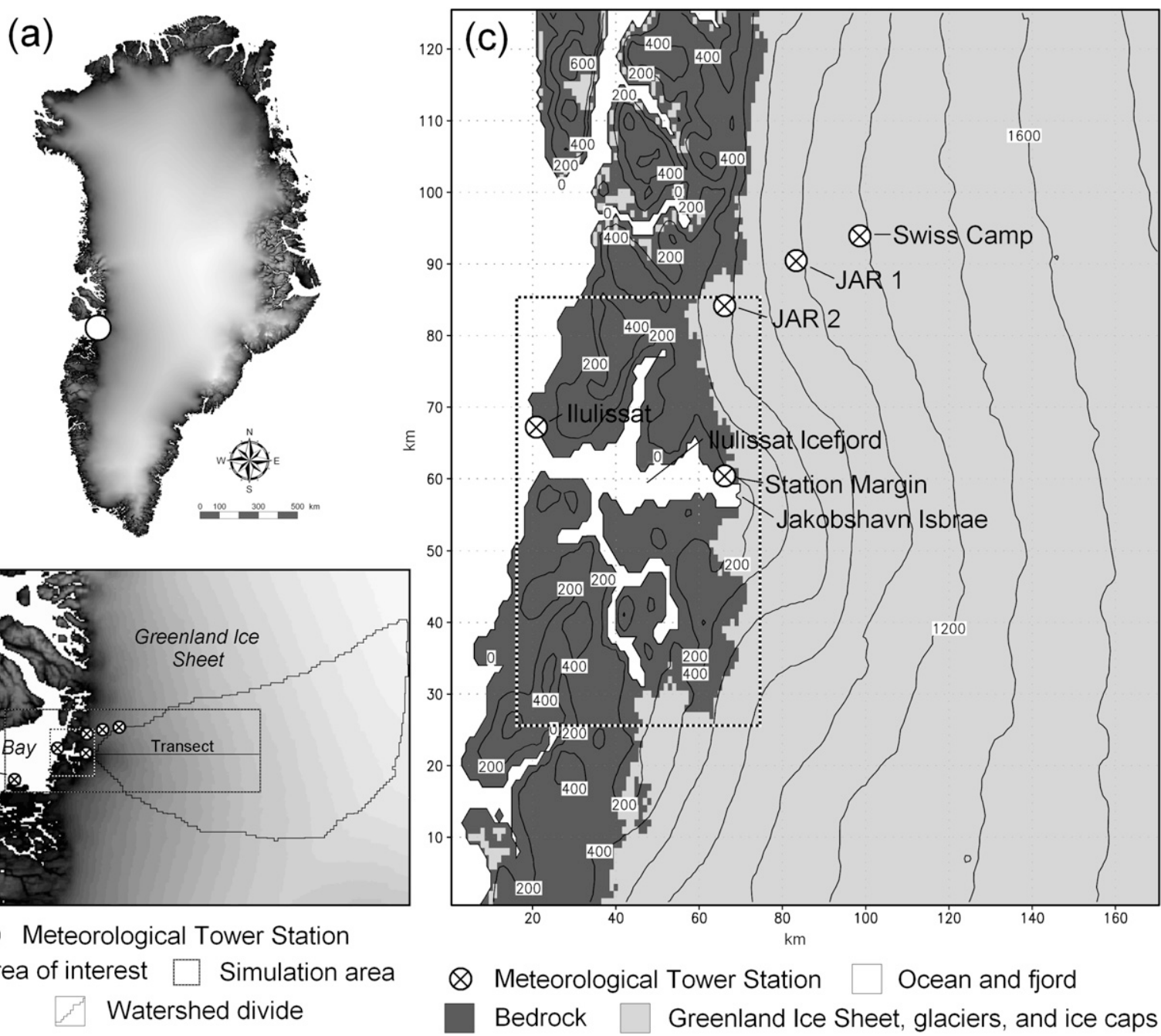

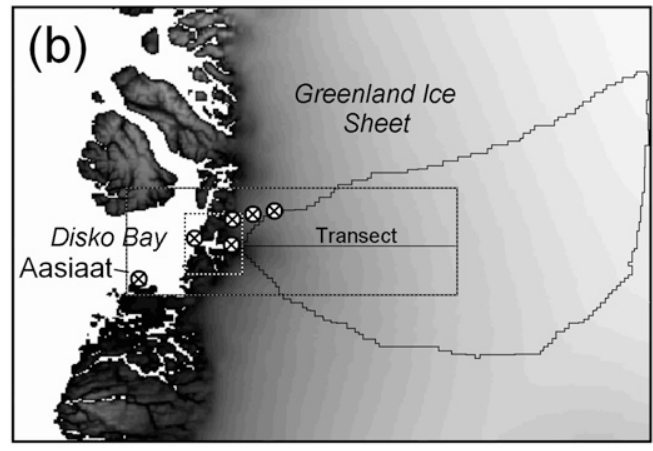

Q Meteorological Tower Station

Area of interest $\square$ Simulation area Watershed divide

\section{Greenland Ice Sheet, glaciers, and ice caps}

FIG. 1. (a) The Ilulissat Icefjord region in west Greenland and (b) the simulation area and the area of interest including the six automatic weather stations. Also, the watershed divide for the Jakobshavn Isbrae catchment is highlighted estimated in HydroFlow, and (c) topography for the region (based on 200-m contour) and surface characteristics are illustrated. The Ilulissat Icefjord area of interest is marked and located inside the dashed square.

(www.smru.st-and.ac.uk/Instrumentation/CTD/) mounted on ringed seals. These data allowed us to compare the effect of runoff events on hydrographic conditions inside the fjord and near tidewater glacier margins during late-summer spike runoff events and during low runoff time intervals.

This study supplements a previous study by Mernild et al. (2010b), in which hydrological processes, including melt extent conditions, SMB, and surface runoff, were analyzed only for the Jakobshavn Isbrae catchment during the years 2001 to 2007 . In the present study, we analyze the overall freshwater flux from land (2009 to 2013) and take into account the spatiotemporal routing and distribution of runoff draining into the entire Ilulissat Icefjord from 214 subcatchments. Runoff is then linked to quasi-continuous salinity and temperature observations, emphasizing the terrestrial runoff impact on hydrographic conditions inside the fjord and near the GrIS tidewater glacier margins.

\section{Study area}

Ilulissat Icefjord $\left(69^{\circ} 10^{\prime} \mathrm{N}, 51^{\circ} 06^{\prime} \mathrm{W}\right)$ is located in west Greenland, south of the town of Ilulissat (formerly Jakobshavn), and it connects to Disko Bay to the west (Figs. 1, 2). The Ilulissat Icefjord system is estimated to be about $620 \mathrm{~km}^{2}$ in area. The main fjord is east-west oriented and about $60 \mathrm{~km}$ in length. Besides the main fjord, the system contains a northern and southern arm. The depth in the main fjord is about $800 \mathrm{~m}$ (almost 

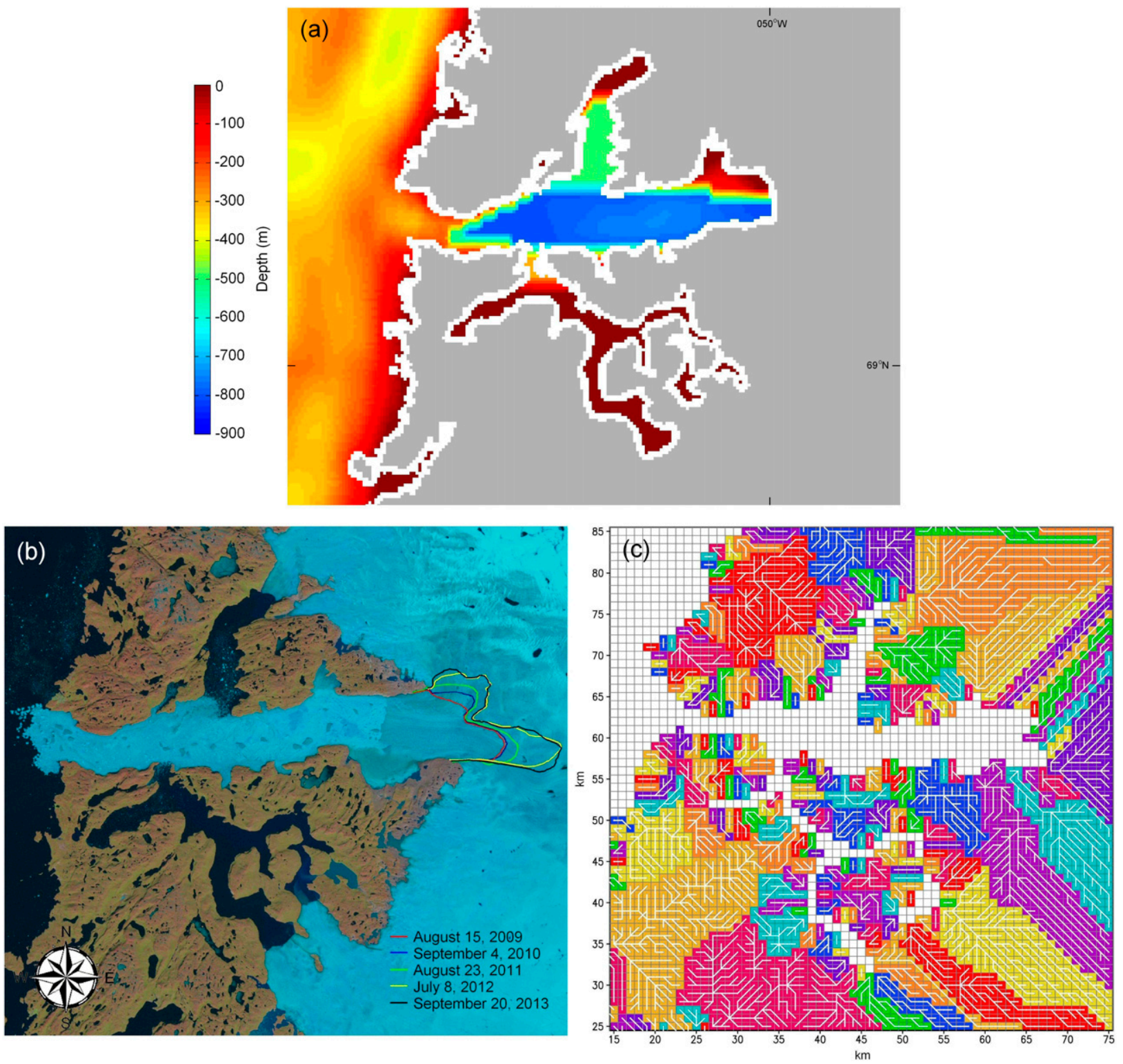

FIG. 2. The Ilulissat Icefjord area of interest: (a) a bathymetric map (Holland et al. 2008); (b) locations of the Jakobshavn Isbrae terminus in mid/late summer 2009-13 used to define an annual time-invariant glacier position for the simulations [background is the Landsat-7 Enhanced Thematic Mapper Plus (ETM+) mosaic, 7 Jul 2001]; and (c) the individual drainage basins $(n=214$; represented by different colors) and stream-river flow network (represented by white lines) are estimated in HydroFlow. Ocean and fjords are indicated by white cells. The 2009 Jakobshavn Isbrae terminus is illustrated by the shape of the white cells.

uniform) (e.g., Gladish et al. 2015), about $500 \mathrm{~m}$ in the northern arm, and about $150 \mathrm{~m}$ in the southern arm (Fig. 2a; Holland et al. 2008), and the grounding line of each of the three tidewater glacier margins are expected to be of similar depths. A submarine trough runs through the Ilulissat Icefjord, where a sill at the mouth of the fjord, adjoining the fjord to Disko Bay, has a depth of $\sim 250 \mathrm{~m}$ (Fig. 2a). The northern and southern arms have an area of about 60 and $210 \mathrm{~km}^{2}$, respectively, and both have an estimated volume of about
$30 \mathrm{~km}^{3}$ (assuming that the fjord cross-section profiles are rectangular).

The Ilulissat Icefjord catchment (estimated to be about $106300 \mathrm{~km}^{2}$ ) ranges in elevation from sea level to above $3000 \mathrm{~m}$ MSL at the GrIS ice divide. Exposed bedrock, sporadic, thin soil cover, and sparse vegetation dominate the ice-free western part of the catchment, whereas the eastern part is covered by the GrIS (Figs. 1,2). Jakobshavn Isbrae is Greenland's largest outlet glacier and a prolific exporter of calved ice $\left(59.8 \pm 2.7 \mathrm{Gt} \mathrm{yr}^{-1}\right.$ for 
TABLE 1. Meteorological input data for Ilulissat Icefjord runoff simulations based on meteorological station data. Stations on the GrIS were Swiss Camp, JAR1, and JAR2 (all provided by University of Colorado at Boulder). Stations off the GrIS were Station Margin (by New York University) and Stations Ilulissat and Aasiaat (by DMI). For locations see Fig. 1.

\begin{tabular}{|c|c|c|c|c|c|}
\hline $\begin{array}{l}\text { Meteorological } \\
\text { stations }\end{array}$ & Location & Position & $\begin{array}{l}\text { Elevation } \\
\text { (m MSL) }\end{array}$ & Data period & Operated by \\
\hline Swiss Camp & GrIS & $69^{\circ} 34^{\prime} 03^{\prime \prime} \mathrm{N}, 49^{\circ} 19^{\prime} 17^{\prime \prime} \mathrm{W}$ & 1140 & 14 May 2009-3 Мay 2013 & $\begin{array}{l}\text { University of Colorado } \\
\text { at Boulder }\end{array}$ \\
\hline JAR1 & GrIS & $69^{\circ} 29^{\prime} 51^{\prime \prime} \mathrm{N}, 49^{\circ} 41^{\prime} 16^{\prime \prime} \mathrm{W}$ & 962 & 1 Sep 2008-16 Jun 2013 & $\begin{array}{l}\text { University of Colorado } \\
\text { at Boulder }\end{array}$ \\
\hline JAR2 & GrIS & $69^{\circ} 25^{\prime} 09^{\prime \prime} \mathrm{N}, 50^{\circ} 03^{\prime} 55^{\prime \prime} \mathrm{W}$ & 542 & 12 May 2009-26 Nov 2012 & $\begin{array}{l}\text { University of Colorado } \\
\text { at Boulder }\end{array}$ \\
\hline Margin & $\begin{array}{l}\text { Outside GrIS } \\
\text { (at the margin) }\end{array}$ & $69^{\circ} 13^{\prime} 20^{\prime \prime} \mathrm{N}, 49^{\circ} 48^{\prime} 57^{\prime \prime} \mathrm{W}$ & 30 & 1 Sep 2008-31 Dec 2013 & New York University \\
\hline Ilulissat & $\begin{array}{l}\text { Outside GrIS } \\
\quad \text { (coastal region) }\end{array}$ & $69^{\circ} 14^{\prime} 00^{\prime \prime} \mathrm{N}, 51^{\circ} 04^{\prime} 00^{\prime \prime} \mathrm{W}$ & 29 & 1 Sep 2008-31 Dec 2013 & $\begin{array}{l}\text { Danish Meteorological } \\
\text { Institute }\end{array}$ \\
\hline Aasiaat & $\begin{array}{l}\text { Outside GrIS } \\
\quad \text { (coastal region) }\end{array}$ & $68^{\circ} 42^{\prime} 00^{\prime \prime} \mathrm{N}, 52^{\circ} 45^{\prime} 00^{\prime \prime} \mathrm{W}$ & 88 & 1 Sep 2008-31 Dec 2013 & $\begin{array}{l}\text { Danish Meteorological } \\
\text { Institute }\end{array}$ \\
\hline
\end{tabular}

2009-13; Howat et al. 2011, updated), draining an area of the GrIS of about $92000-100780 \mathrm{~km}^{2}$ (estimated by, e.g., Luckman and Murray 2005; Rignot and Kanagaratnam 2006; Mernild and Liston 2012). Jakobshavn Isbrae has lost mass more rapidly than any other GrIS outlet glacier in recent years (e.g., Howat et al. 2011; Joughin et al. 2014).

Ilulissat Icefjord is located in what is considered to be the low Arctic (Born and Bocher 2001). In the town of Ilulissat, the local mean annual air temperature (MAAT) is $-2.9^{\circ} \mathrm{C}$ (2001-11) (e.g., Hanna et al. 2012; Mernild et al. 2014), and mean annual precipitation ranges between 300- and 700-mm water equivalent (WE) (2001-11) (Mernild et al. 2015). The annual precipitation decreases with increasing distance from the fjord mouth toward the GrIS margin (Mernild et al. 2015).

\section{Meteorological and hydrographic data}

Observed data from six automatic weather stations (AWS) were used as model forcing (Fig. 1; Table 1). Swiss Camp, JAR1, and JAR2 are all part of the Greenland Climate Network (GC-Net) and located on the ice sheet, being representative of the GrIS conditions [for additional information about the GC-Net AWS, see Steffen (1995) and Steffen and Box (2001)]. The AWS margin operated by New York University is representative of the local GrIS margin conditions. Station Jakobshavn and Egedesminde (Aasiaat), two synoptic Danish Meteorological Institute (DMI) World Meteorological Organization AWS are located east and south of the Disko Bay region and are representative of the local coastal conditions.

It is well known that accurate measurement of precipitation remains challenging, with errors for solid precipitation frequently ranging from $20 \%$ to $50 \%$ because of wetting losses and undercatch in windy conditions (Rasmussen et al. 2012), where wetting loss results from water subject to evaporation from the internal walls of the gauge (e.g., Goodison et al. 1989; Metcalfe et al. 1994). These errors affect the quality and accuracy of precipitation data. To account for such errors, the precipitation dataset observed at the DMI AWS (using a Helman-Nipher shield) was bias-corrected following Allerup et al. (1998, 2000). Also, observed solid (snow) precipitation from JAR1, JAR2, and Swiss Camp was calculated from snow depth sounder observations after the sounder data noise was erased and used as forcing. The snow depth dataset is assumed to be accurate within $\pm 10 \%-15 \%$ [see Mernild et al. $(2007,2008 \mathrm{c})$ for information on accuracy calculations].

\section{Observations and model description, setup, uncertainty, and validation}

\section{a. Observations from Ilulissat Icefjord}

Hydrographic observations in Ilulissat Icefjord have been collected since 1 August 2013, where CTD SRDL instruments were mounted on two ringed seals (seals 10 13 and 14-13) with the aim of continuously measuring (maximum 12 depth profiles per day; however, the typically number of profiles is between five to six per day) water salinity, water temperature, depth, and the location (coordinates) of the seals between August and December. Ringed seals (Pusa hispida) inhabit both offshore and nearshore areas throughout the Arctic. Juvenile ringed seals, and probably also offshore breeding ringed seals, have a home range that may be hundreds or even thousands of kilometers wide. However, recent tagging of adult ringed seals on several coastal locations in Greenland (http://efdl_ems.cims.nyu. edu/srdl_seals/overview.html) has shown a high degree 
of site fidelity and small home ranges (like a single fjord system). This tendency to stay in a single fjord system makes them a suitable species for collecting hydrographic information of the waters in the Ilulissat Icefjord and near GrIS tidewater glaciers along the coast of Greenland. Earlier studies have used deep diving hooded seals (Cystophora cristata) as a valuable platform for hydrographic observations in coastal and offshore waters near Greenland (Straneo et al. 2010; Sutherland et al. 2013). The accuracy of water temperature measurements of the CTD SRDL instruments is $0.005^{\circ} \mathrm{C}$ and of conductivity is $0.01 \mathrm{mS} \mathrm{cm}^{-1}$, which translates into a salinity accuracy of about $0.02 \mathrm{~g} \mathrm{~kg}^{-1}$. New York University and the Greenland Institute of Natural Resources operate the ringed seal program.

\section{b. Model description}

SnowModel (Liston and Elder 2006a,b; Mernild et al. 2006) is a spatially distributed modeling system (3D model) that simulates meteorological conditions, surface energy, and moisture exchanges including snow and glacier melt, multilayer heat and mass transfer processes within the snow (e.g., snowpack temperature and density evolution), and runoff to downstream areas and surrounding oceans. SnowModel does not include ice flow or basal sliding. The model is designed for application in all landscapes, climates, and conditions where snow and ice occur. SnowModel and its various submodels have been used successfully to simulate snow and ice accumulation and ablation processes, including runoff, throughout the Arctic, including Greenland (Mernild et al. 2006, 2007, 2008c, 2010b, 2011b; Liston et al. 2007; Mernild and Liston 2010; Liston and Hiemstra 2011). SnowModel is an aggregation of several submodels: MicroMet is a quasi-physically based, high-resolution meteorological distribution model (Liston and Elder 2006b); EnBal calculates surface energy exchanges (Liston 1995; Liston et al. 1999); SnowTran-3D accounts for snow redistribution by wind (Liston and Sturm 1998, 2002; Liston et al. 2007); SnowPack-ML simulates the role of surface meltwater percolating into, and refreezing within, snow and firn layers that contribute significantly to the evolution of snow and ice densities and moisture available for runoff (Liston and Hall 1995; Liston and Mernild 2012); and HydroFlow links runoff production from landbased snowmelt and ice melt processes to downstream areas based on a gridded, linear-reservoir routing model (Liston and Mernild 2012; Mernild and Liston 2012).

The inputs required for SnowModel include timevarying fields of point air temperature, relative humidity, precipitation, wind speed, and wind direction obtained from AWS located within the simulation domain and spatially distributed time-invariant fields of topography and land-cover types. MicroMet provided the gridded meteorological forcing data required by SnowModel. The model uses known relationships between meteorological variables and the surrounding landscape (primarily topography) to distribute those variables over any given landscape in physically plausible and computationally efficient ways. At each time step, MicroMet calculates and distributes air temperature, relative humidity, wind speed, wind direction, incoming solar radiation, incoming longwave radiation, surface pressure, and precipitation and makes them accessible to SnowModel.

\section{c. Model setup and uncertainty}

Howat et al. (2014) provided the digital elevation model (DEM) used within SnowModel as part of the GrIS Mapping Project (GIMP). The land-cover data were obtained from the U.S. Geological Survey (USGS) North American Land Cover Characteristics Database, version 2.0. The SnowModel simulations were performed for the Ilulissat Icefjord catchment using a 1-km, aggregated grid increment and daily time step over the period September 2008-December 2013. The simulation area was clipped to yield a $500 \mathrm{~km}$ by $125 \mathrm{~km}$ domain $\left(62500 \mathrm{~km}^{2}\right.$; Fig. 1b), including the area of interest $60 \mathrm{~km}$ by $60 \mathrm{~km}\left(3600 \mathrm{~km}^{2}\right.$; Fig. 1c). The frontal position of Jakobshavn Isbrae during the late summer of 2009-13 (Fig. 2b) was determined by Ian Joughin (University of Washington) from TerraSAR-X data and used in SnowModel. For the purposes of this study, the Ilulissat Icefjord catchment has been divided into 214 subcatchments (ranging in size from $2 \mathrm{~km}^{2}$ to $100780 \mathrm{~km}^{2}$ ) based on HydroFlow simulations, each draining into specific parts of the fjord, including the two fjord arms (Fig. 2c). A total of 29 subcatchments drain parts of the GrIS, and 185 subcatchments drain the low-elevated ice-free western part of the Ilulissat Icefjord catchment. Userdefined SnowModel constants are shown in Table 2 [for parameter definitions and further details, see Liston and Sturm $(1998,2002)]$ and validation parameters are shown in Table 3.

The use of a time-invariant GrIS DEM must produce melt rate errors in areas where the surface elevation has actually changed (i.e., where dynamic thinning of Jakobshavn Isbrae has occurred). In the simulations presented here, dynamic thinning is assumed to be a secondorder process and is not accounted. On the other hand, the upper bounds for the meltwater generated at the ice bed because of geothermal heating and motion-induced basal frictional heating were estimated [for equations and calculation assumptions, see Mernild et al. (2010a)]. Geothermal meltwater volume contributions were estimated to be $0.01 \mathrm{~km}^{3} \mathrm{yr}^{-1}$, which was two orders of magnitude less than the contributions from runoff and ice discharge (Table 4) 
TABLE 2. User-defined constants used in the SnowModel and IceHydro simulations [for parameter definitions, see Liston and Sturm (1998) and Mernild and Liston (2012)]. The values are fixed throughout the simulation period.

\begin{tabular}{|c|c|c|}
\hline Symbol & Value & Parameter \\
\hline \multirow[t]{4}{*}{$C_{v}$} & & Vegetation snow-holding depth (equal surface roughness length $\left.Z_{0}\right)(\mathrm{m})$ \\
\hline & 0.50 & Barren bedrock/vegetation \\
\hline & 0.01 & Lake/fjord/ocean (only when it is frozen) \\
\hline & 0.01 & Ice/snow \\
\hline$F$ & 500.0 & Snow equilibrium fetch distance $(\mathrm{m})$ \\
\hline$U^{*} t$ & 0.25 & Threshold wind shear velocity $\left(\mathrm{m} \mathrm{s}^{-1}\right)$ \\
\hline$D t$ & 1 & Time step (d) \\
\hline \multirow[t]{2}{*}{$d x=d y$} & & Grid cell increment $(\mathrm{km})$ \\
\hline & 1.0 & Jakobshavn Fjord simulation area \\
\hline \multirow[t]{3}{*}{$A$} & & Surface albedo \\
\hline & $0.5-0.8$ & Snow (variable snow albedo according to surface snow characteristics) \\
\hline & 0.4 & Ice \\
\hline \multirow[t]{3}{*}{$P$} & & Surface density $\left(\mathrm{kg} \mathrm{m}^{-3}\right)$ \\
\hline & 280 & Snow \\
\hline & 910 & Ice \\
\hline$\rho_{s}$ & 550 & Saturated snow density $\left(\mathrm{kg} \mathrm{m}^{-3}\right)$ \\
\hline \multirow[t]{5}{*}{$V_{s}$} & & $\begin{array}{l}\text { Flow velocities for the slow-response flow: The slow time scale accounts for the time it takes runoff at } \\
\text { each individual grid cell, usually produced from liquid precipitation or snowmelt and/or ice melt, to } \\
\text { enter the routing network (the fast-response flow). The slow time scale generally accounts for } \\
\text { transport within the snow and ice matrices (for the case of glaciers and ice sheets) and soil (for the } \\
\text { case of snow-covered and snow-free land), and the fast time scale generally represents some kind of } \\
\text { channel flow, such as that represented by supraglacial, englacial, or subglacial flow (for the case of } \\
\text { glaciers and ice sheets) and river and stream channels (for the case of snow-covered and snow-free } \\
\text { land) }\left(\mathrm{m} \mathrm{s}^{-1}\right) \text {. }\end{array}$ \\
\hline & 0.12 & Snow-covered ice \\
\hline & 0.20 & Snow-free ice \\
\hline & 0.10 & Snow-covered land \\
\hline & 0.08 & Snow-free land \\
\hline
\end{tabular}

and can therefore be ignored. The maximum rate of basal melt due to frictional heating caused by ice sliding over the bed was calculated to be $0.6 \mathrm{~km}^{3} \mathrm{yr}^{-1}$ (which was included in the freshwater budget). Also, the simulated precipitation received over the surface area of Ilulissat Icefjord was estimated at $0.2 \pm<0.1 \mathrm{~km}^{3} \mathrm{yr}^{-1}$, equal to about $1 \%$ of the average total freshwater flux (Table 4 ).

\section{d. Model calibration and validation}

Specifically for the GrIS, SnowModel has been successfully tested against independent in situ observations of meteorological variables (Mernild et al. 2008c, 2010c,a), passive microwave-derived and Moderate Resolution Imaging Spectroradiometer (MODIS) satellitederived melt extents (Mernild et al. 2008c, 2010c, 2011a), snow and ice surface melt rates (Mernild et al. 2010c), end-of-winter snow depth or snow water equivalent (SWE) depth observations (Mernild et al. 2006, 2007, 2010b, 2010c), and river runoff [Mernild et al. 2008a, 2011a; Liston and Mernild 2012; a summary table for the different SnowModel tests is shown in Mernild et al. (2009)]. Based on experiences from these studies with

TABLE 3. Observed and modeled snow and SWE depth for Swiss Camp for 2009 through 2013 and simulated ELA for the Ilulissat Icefjord catchment (for transect, see Fig. 1).

\begin{tabular}{|c|c|c|c|c|c|c|}
\hline & & 2009 & 2010 & 2011 & 2012 & 2013 \\
\hline Swiss Camp snow depth (m) & Observed & 1.15 (13 May) & 0.84 (17 May) & 0.80 (22 May) & 1.00 (5 May) & 1.09 (15 May) \\
\hline Swiss Camp SWE depth (m WE) & Observed & 0.38 (13 May) & 0.25 (17 May) & 0.22 (22 May) & 0.33 (5 May) & 0.36 (15 May) \\
\hline Swiss Camp SWE depth (m WE) & $\begin{array}{l}\text { Simulated based on } \\
\text { iterative SWE } \\
\text { routines }\end{array}$ & 0.39 (13 May) & 0.26 (17 May) & 0.23 (22 May) & 0.35 (5 May) & 0.36 (15 May) \\
\hline ELA (m MSL) & Observed & $1680 *$ & $1780 *$ & $1800 *$ & $2690 * *$ & $1500 * *$ \\
\hline ELA (m MSL) & Simulated & 1560 & 1800 & 1850 & 2390 & 1670 \\
\hline
\end{tabular}

* Observed ELA at Jakobshavn Isbrae, west Greenland (McGrath et al. 2013).

** Observed ELA along the K transect near Kangerlussuaq, west Greenland (Box et al. 2012; Tedesco et al. 2013). 
TABLE 4. Freshwater flux to Ilulissat Icefjord based on simulated runoff, satellite-derived ice discharge from Jakobshavn Isbrae, precipitation at the fjord surface area, subglacial geothermal melting, and subglacial frictional melting due to basal ice motion. Mean freshwater flux to Ilulissat Icefjord is calculated based on mean values from each input component. Here, years indicate calendar years. For 2013, no ice discharge was available from Jakobshavn Isbrae indicated with a dashed line. The type of freshwater and locations is highlighted in italic.

\begin{tabular}{|c|c|c|c|c|c|c|}
\hline & 2009 & 2010 & 2011 & 2012 & 2013 & 2009-213 \\
\hline $\begin{array}{l}\text { Simulated GrIS Jakobshavn Isbrae catchment } \\
\text { runoff and error }\left(\mathrm{km}^{3}\right) \text { and the percentage } \\
\text { of the overall Ilulissat Icefjord runoff }\end{array}$ & $2.5 \pm 0.4$ & $4.5 \pm 0.7$ & $4.7 \pm 0.7$ & $9.3 \pm 1.3$ & $3.9 \pm 0.6$ & $5.0 \pm 0.7(\sim 50 \%)$ \\
\hline $\begin{array}{l}\text { Simulated Ilulissat Icefjord runoff and error } \\
\left(\mathrm{km}^{3}\right) \text { and percentage of the overall fresh- } \\
\text { water flux to the Ilulissat Icefjord }\end{array}$ & $7.1 \pm 1.1$ & $9.9 \pm 1.5$ & $10.1 \pm 1.5$ & $14.4 \pm 2.2$ & $8.1 \pm 1.2$ & $9.9 \pm 1.5(14 \%)$ \\
\hline $\begin{array}{l}\text { GrIS Jakobshavn Isbrae catchment ice dis- } \\
\text { charge and error }\left(\mathrm{km}^{3}\right) \text { (Howat et al. 2011, } \\
\text { updated), and percentage of the overall } \\
\text { freshwater flux to the Ilulissat Icefjord }\end{array}$ & $57.6 \pm 2.4$ & $57.8 \pm 2.5$ & $58.5 \pm 3.1$ & $61.7 \pm 2.8$ & - & $59.8 \pm 2.7(85 \%)$ \\
\hline $\begin{array}{l}\text { Simulated precipitation (i.e., rain and snow } \\
\text { accumulation on sea ice) at the Ilulissat } \\
\text { Icefjord surface area }\left(626 \mathrm{~km}^{2}\right) \text {, including } \\
\text { error }\left(\mathrm{km}^{3}\right)\end{array}$ & $0.2 \pm<0.1$ & $0.4 \pm<0.1$ & $0.3 \pm<0.1$ & $0.4 \pm<0.1$ & $0.3 \pm<0.1$ & $0.3 \pm<0.1$ \\
\hline Subglacial geothermal melting $\left(\mathrm{km}^{3}\right)$ & 0.01 & 0.01 & 0.01 & 0.01 & 0.01 & 0.01 \\
\hline $\begin{array}{l}\text { Subglacial frictional melting due to basal ice } \\
\text { motion }\left(\mathrm{km}^{3}\right)\end{array}$ & 0.6 & 0.6 & 0.6 & 0.6 & 0.6 & 0.6 \\
\hline $\begin{array}{l}\text { Freshwater contribution to the Ilulissat Ice- } \\
\text { fjord }\left(\mathrm{km}^{3}\right)\end{array}$ & $65.5 \pm 3.5$ & $68.7 \pm 4.0$ & $69.5 \pm 4.6$ & $77.1 \pm 5.0$ & - & $70.6 \pm 4.2$ \\
\hline
\end{tabular}

regards to the testing of winter and summer processes, the combination of MicroMet- and SnowModel-generated grid cell rainfall, snowmelt, and ice melt runoff is assessed to be of sufficient quality to drive the HydroFlow runoff simulations presented here. Nevertheless, it is important to remember that the absence of supraglacial, englacial, and subglacial meltwater storage in the SnowModel/ HydroFlow calculations may influence the spatial and temporal distributions of simulated runoff to Ilulissat Icefjord.

Additionally, the general performance of SnowModel to simulate both winter and summer processes in the Jakobshavn Isbrae catchment (2001-07) has been assessed by Mernild et al. (2010c). To further assess the performance of SnowModel for the entire Ilulissat Icefjord catchment, both the end-of-winter SWE depth and the location of W-GrIS equilibrium line altitude (ELA; for the west GrIS, the elevation where the sum of accumulation and ablation is zero) were compared and adjusted against observational data.

The annual observed SWE depth was an average of 10 different measurements at the Swiss Camp (based on snowpack depth and snowpack density measurements). First, the simulated SWE depth was calibrated against the observed average SWE depth at Swiss Camp on 13 May (2009), 17 May (2010), 22 May (2011), 5 May (2012), and 15 May (2013) by using the iterative SWE routines described in detail by Mernild et al. [2006; Eqs. (3) and (4)]. Based on these iterative routines, the simulated Swiss Camp SWE depths for the specific dates were calculated to be within $1 \%$ of the observed average SWE depth. The iterative procedure was performed for each year. In Table 3, both the simulated, adjusted SWE (henceforth referred to as simulated SWE depth) and observed SWE are given.

Second, the annual simulated W-GrIS ELA for the profile (transect) illustrated in Fig. 1b (going from the margin of Jakobshavn Isbrae toward the GrIS ice divide) was verified against observations of ELA (Table 3). The simulated W-GrIS ELA for Jakobshavn Isbrae for 2009-13 was located in the elevation band from 1560 to 1850 m MSL (Table 3; Fig. 3) except for the year 2012. In the extreme surface melt year 2012, the ELA was at $2390 \mathrm{~m}$ MSL. A blocking high pressure feature, associated with negative North Atlantic Oscillation conditions, was present in the midtroposphere over Greenland for much of the summer, advecting relatively warm southerly winds over the western flank of the ice sheet and forming a "heat dome" over Greenland that led to widespread enhanced surface melting (Hanna et al. 2013b). The simulated mean W-GrIS ELA for 2009-13 was about $1850 \pm 300 \mathrm{~m} \mathrm{MSL}$ (where \pm equals one standard deviation), which is in accordance with the observed ELA (Box et al. 2012; McGrath et al. 2013; Tedesco et al. 2013) for the Jakobshavn-Kangerlussuaq area (along the K transect) of about $1900 \pm 450 \mathrm{~m}$ MSL (Table 3). Modeled mean ELA is thus considered to be in accordance with observed ELA. 

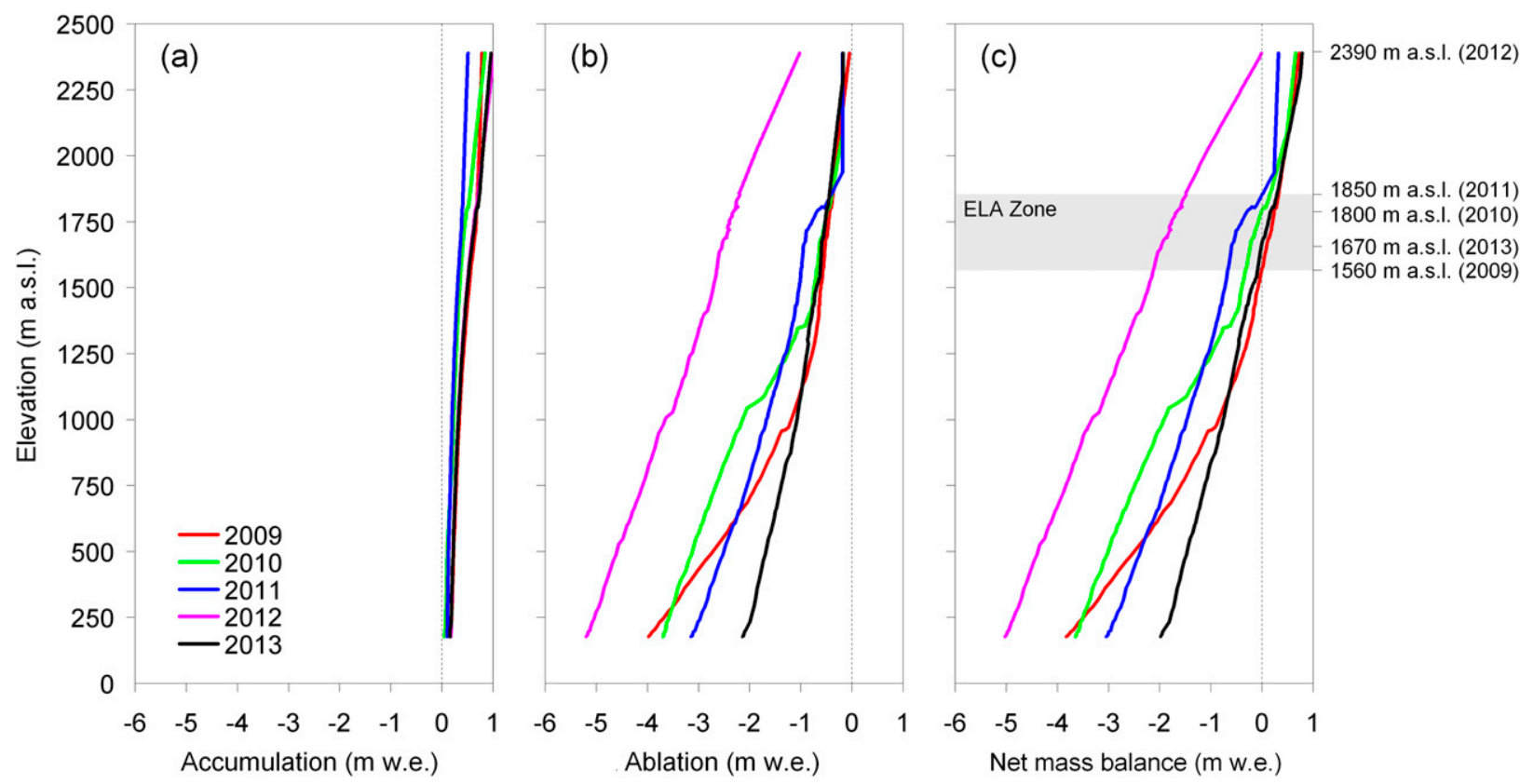

FIG. 3. (a) Modeled surface accumulation (snow accumulation); (b) surface ablation (runoff, sublimation, and evaporation); and (c) net mass balance in relation to elevation for the years 2009-13 (years from 1 Sep to 31 Aug) for a transect in the Jakobshavn Isbrae drainage area (the transect is illustrated in Fig. 1b).

\section{Results and discussion}

\section{a. Seasonal and annual distribution of freshwater flux}

In Fig. 4a, the simulated mean monthly Jakobshavn Isbrae freshwater flux is shown, illustrating on average a minimum flux in December of $4.50 \pm 0.05 \mathrm{~km}^{3}$ (where \pm henceforth equals one standard error) and a maximum flux in July of $7.43 \pm 0.11 \mathrm{~km}^{3}$. The freshwater flux is a composite of both ice discharge and runoff, where the mean monthly ice discharge varies from minimum $4.50 \pm 0.05 \mathrm{~km}^{3}$ in December to a maximum of $4.95 \pm$ $0.11 \mathrm{~km}^{3}$ in July [for detailed information about the estimation of ice discharge data, see Howat et al. (2011)] and runoff from zero (no runoff) in October through April to $2.47 \pm 0.67 \mathrm{~km}^{3}$ in July (Figs. $4 \mathrm{a}$ and $4 \mathrm{c}$ ). Both the satellite-derived ice discharge and simulated runoff are highest during summer (June, July, and August) and lowest or zero during winter (December, January, and February), following the seasonal variability in incoming solar radiation [since incoming solar radiation is the source of energy that primarily melts high latitude snow covers (Liston and Hiemstra 2011)] and in air temperature. A detailed evaluation of surface air temperature records was done by Hanna et al. (2012) yielding, on average for Ilulissat, a mean summer and winter temperature of $7.4^{\circ} \pm 0.7^{\circ} \mathrm{C}$ and $-10.4^{\circ} \pm 2.5^{\circ} \mathrm{C}$ (2001-11), respectively.

For the months May-October, the mean Jakobshavn Isbrae catchment runoff was simulated to be $<1 \%, 14 \%$,
$50 \%, 34 \%,<1 \%$, and $<1 \%$ of the monthly ice discharge coming from Jakobshavn Isbrae (Fig. 4a), respectively. The overall Ilulissat Icefjord runoff was 7\% (May), 42\% (June), 91\% (July), 55\% (August), 5\% (September), and $<1 \%$ (October and November) of the total ice discharge (Fig. 4b). Regarding the fraction of runoff from the Jakobshavn Isbrae catchment compared to the overall runoff to the Ilulissat Icefjord, it was found to be approximately $50 \%$ (Table 4), where the majority of runoff in both July and August originated from the Jakobshavn Isbrae (and in May-June) and runoff in SeptemberNovember originated from the other subcatchments, especially from snowpack melt or rain events in the lowelevated area west of the GrIS margin (Fig. 4c). On an annual scale, the Jakobshavn Isbrae runoff of $5.0 \pm$ $0.7 \mathrm{~km}^{3}$ (Table 4 ) was on average about $8 \%$ of the annual ice discharge of $59.8 \pm 2.7 \mathrm{~km}^{3}$, and the annual Ilulissat Icefjord runoff of $9.9 \pm 1.5 \mathrm{~km}^{3}$ was on average about $17 \%$ of the annual ice discharged by Jakobshavn Isbrae. In total for Ilulissat Icefjord, the annual terrestrial freshwater contribution-including ice discharge, runoff, and contributions from simulated precipitation over the Ilulissat Icefjord surface area, subglacial geothermal melting, and subglacial frictional melting due to basal ice motion-was on average $70.6 \pm 4.2 \mathrm{~km}^{3}$ (Table 4). For comparison, the overall freshwater flux to Sermilik Fjord, southeast Greenland, was on average $40.4 \pm 4.9 \mathrm{~km}^{3}$ from 1999 to 2008, including ice discharge from Helheim, Fenris, and Midgaard Glaciers (Mernild et al. 2010a). 

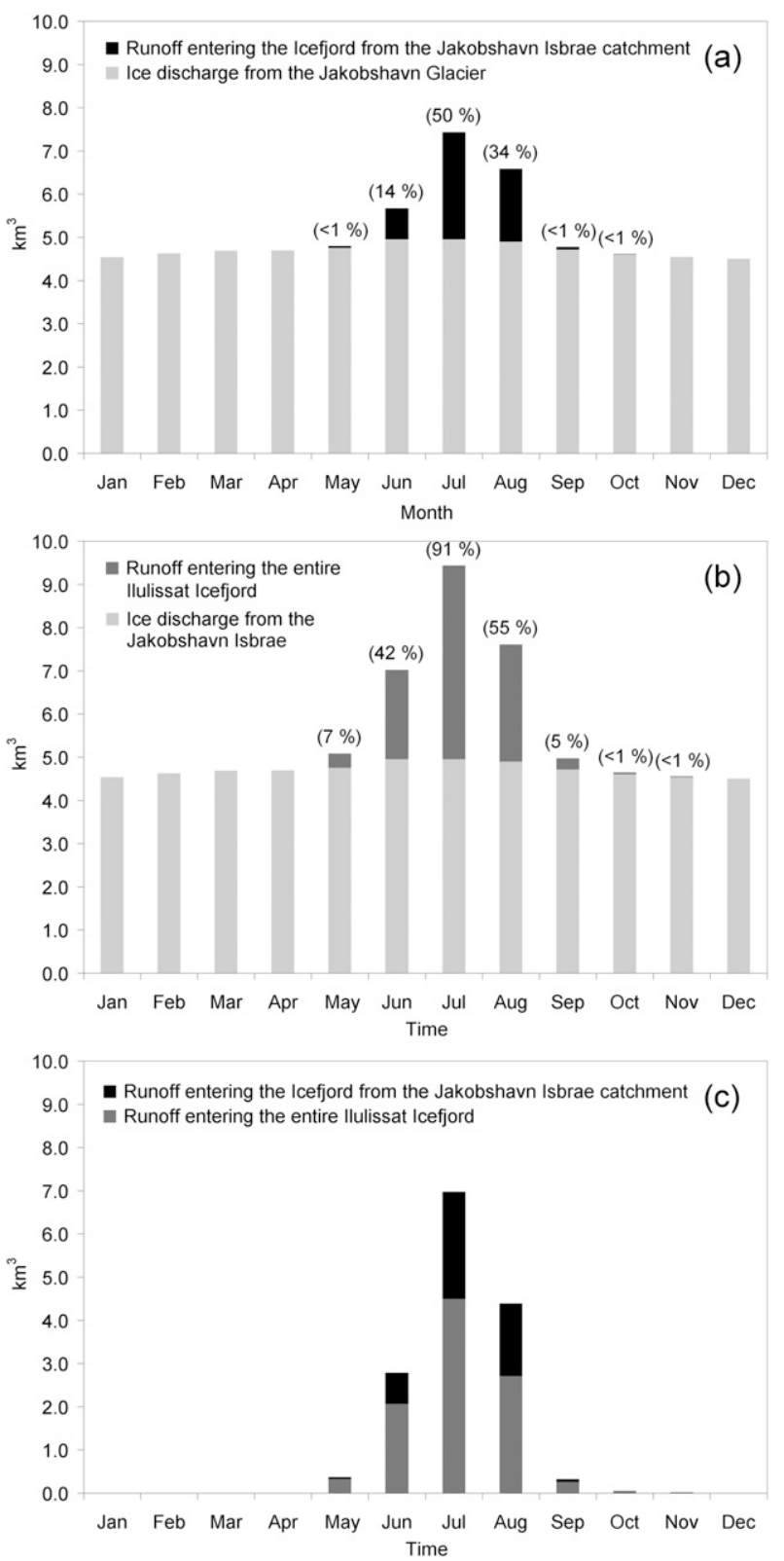

FIG. 4. Mean monthly (a) Jakobshavn Isbrae ice discharge (2009-10) (Howat et al. 2011) and simulated runoff entering the Icefjord from the Jakobshavn Isbrae catchment (2009-13). The amount of freshwater runoff relative to the ice discharge from the Jakobshavn Isbrae is shown as a percentage (in brackets); (b) Jakobshavn Isbrae ice discharge and simulated runoff entering the entire Ilulissat Icefjord; and (c) simulated runoff entering the Ilulissat Icefjord from the Jakobshavn Isbrae catchment and simulated runoff entering the entire Ilulissat Icefjord.

During the period 2001-11, both ice discharge $\left(r^{2}=\right.$ $0.83, p<0.01$, where $r^{2}$ is the explained variance and $p$ is level of significance) (see also Howat et al. 2014) and runoff increased from Jakobshavn Isbrae $\left(r^{2}=0.28, p<\right.$ $0.05)$ (Fig. 5). The 2001-13 glacier runoff time series was a composite of data from 2001 to 2007 (Mernild et al. 2010c) and from 2009 to 2013 (this study). At the same time, over the west coast of Greenland, very strong recent warming (locally $>10^{\circ} \mathrm{C}$ in MAAT) has occurred since 1991 (Hanna et al. 2012). For the town of Ilulissat, however, the warming was estimated to be about $1^{\circ} \mathrm{C}$ from 2001 to 2011, with the greatest seasonal change of $4.1^{\circ} \mathrm{C}$ during winter (Hanna et al. 2012).

\section{b. Spatiotemporal distribution of runoff}

The spatial distribution of simulated runoff to Ilulissat Icefjord from each of the 214 subcatchments is illustrated in detail in Fig. 6, where the area of each circle is proportional to the amount of runoff. For the period 2009-13 (Fig. 6a), the mean subcatchment runoff was spatially unevenly distributed, indicating that the majority of runoff to the fjord system came from the catchments, which cover parts of the GrIS [having a mean specific runoff (runoff per unit drainage area per time) of $38.4 \pm 5.4 \mathrm{~L} \mathrm{~km}^{-2} \mathrm{~s}^{-1}$ ] where less runoff came from the ice-free and relatively minor subcatchments $\left(18.4 \pm 3.6 \mathrm{~L} \mathrm{~km}^{-2} \mathrm{~s}^{-1}\right)$. This spatial distribution in runoff was also observed for the extreme runoff year 2012 [the year with maximum annual and daily runoff (Table 4; Fig. 6d) influenced by the heat dome over Greenland that led to the widespread surface melting (Hanna et al. 2013b)]. For example, a comparison of runoff only from the subcatchments not covered by the GrIS ( $n=185)$ illustrates that the mean 2009-13 runoff contribution to the fjord was higher than the 2012 simulated runoff by about $7 \%$. This example indicates that the heat dome over Greenland in 2012 affected the runoff flux mainly by melting ice in the largest subcatchments covered by the GrIS.

As the terrestrial subcatchment runoff to Ilulissat Icefjord is spatially unevenly distributed, the northern and southern fjord arms receive different proportions of runoff. The northern arm received on average $5 \% \pm 1 \%$ $\left(0.5 \pm 0.1 \mathrm{~km}^{3}\right)$, the southern arm received $28 \% \pm 5 \%$ $\left(2.7 \pm 0.2 \mathrm{~km}^{3}\right)$, and the inner part of Ilulissat Icefjord (defined as east of the northern fjord arm) received $67 \% \pm 5 \%\left(6.7 \pm 1.1 \mathrm{~km}^{3}\right)$ of SnowModel estimated runoff (2009-13) (Fig. 6c). Together with the satellitederived ice discharge from Jakobshavn Isbrae, the inner part of the Ilulissat Icefjord received the majority (about $95 \%$ ) of all terrestrial water fluxes entering the fjord system. Such a spatiotemporal distribution in terrestrial water fluxes (including runoff) entering the fjord system may have an influence on the hydrographic conditions inside the fjord, and therefore, as an example, the variability in terrestrial runoff was linked to salinity and temperature observations inside the fjord and near tidewater glacier margins. 


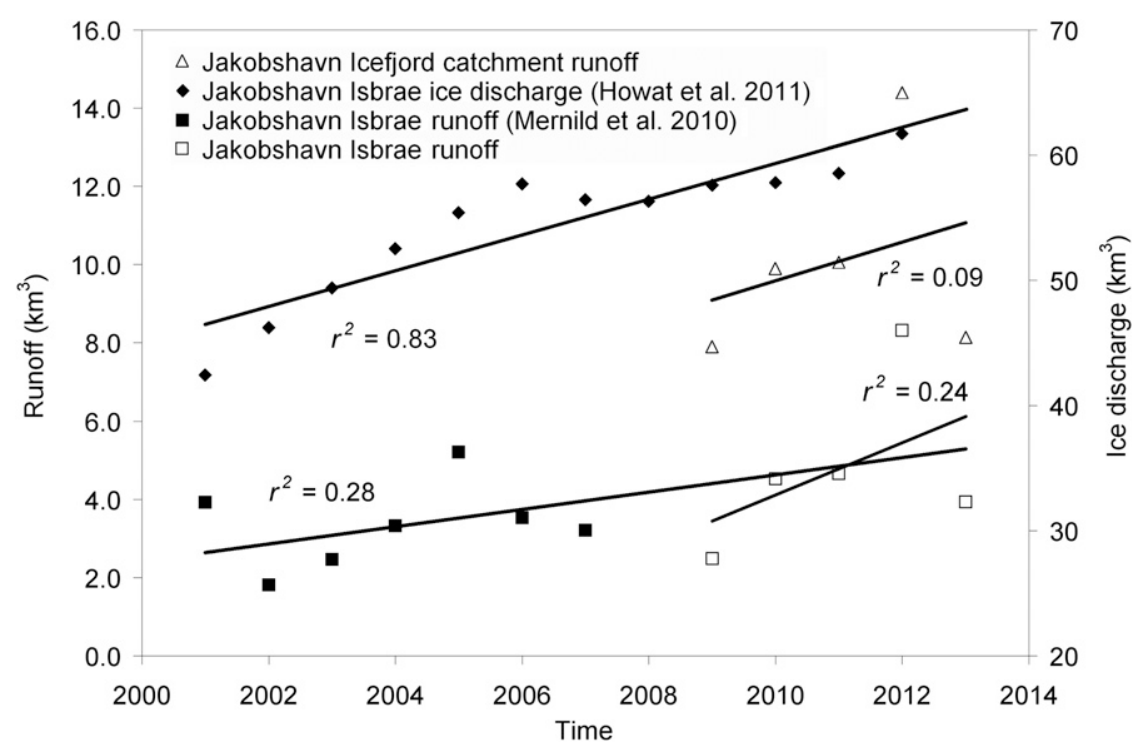

FIG. 5. Annual time series for simulated runoff from 2001 to 2013 for the Jakobshavn Isbrae catchment and Ilulissat Icefjord catchment and estimated ice discharge from the Jakobshavn Isbrae (Howat et al. 2011). The solid lines illustrate the linear trends.

\section{c. Link between terrestrial runoff variability and seal- obtained salinity and temperature observations}

To elucidate the impact on the fjord hydrography from the temporal variability in runoff, continuous salinity and water temperature observations from ringed seals were used (Fig. 7). In Fig. 7, time series are displayed from the two ringed seals (10-13 and 14-13) to show the seasonal variability in observed water salinity, temperature, depth, and the location of the seals inside Ilulissat Icefjord for the period of August through December 2013. Since the seals dove throughout the fjord, the time series in Figs. $7 \mathrm{a}$ and $7 \mathrm{~b}$ are composites of salinity and temperature observations from different positions within the fjord. One of the seals (10-13), however, moved between the different fjord arms and the main fjord (Fig. 7a). The mobility of the two seals is illustrated on the maps in Fig. 7, where positions are shown for both seals. Based on the geographical positions, seal 10-13 was more mobile than seal 14-13 and spent more time near the outlet glacier margin in the southern fjord arm in August-October (illustrated by the vertical dotted lines in Fig. 7a) and in the main fjord near the margin of the Jakobshavn Isbrae in OctoberDecember. Seal 14-13 spent all the time from August to December in the main fjord near the margin of the Jakobshavn Isbrae.

From August to mid-October the upper about $25 \mathrm{~m}$ of the water column indicates salinities in the range of $\sim 23-32$ psu, and from mid-October to December surface salinities were greater than 31-32 psu (Figs. 7, 8a,b;
Table 5). Below this "fresh surface cap," salinities were much more homogeneous [both for the main fjord and the southern fjord arm (Figs. 8a,b; Table 5)], especially below about $150-200 \mathrm{~m}$ where salinities were in the range 32.7-34.1 psu (Fig. 7; Table 5). Such stratification with fresher waters at the surface is typically consistent with terrestrial runoff and surface ice melt (Straneo et al. 2012). The change in water temperature from August to December indicates an average drop in temperature in the upper part of the water column within the main fjord (Fig. 8a), whereas on average the temperature increased for the southern fjord arm (Fig. 8b). These different patterns in salinity and temperature conditions between the main fjord and the southern fjord are further shown on the temperature-salinity $(T-S)$ plot (Fig. $8 \mathrm{c})$. The $T-S$ plot for the main fjord indicates that a drop in temperature equals a drop in salinity. However, at 0 - to 2-m depth, a drop in salinity equals an increase in water temperature probably because of runoff entering the upper part of the water column. For the southern fjord arm, the shape of the $T-S$ profile is different (having a C-shape form). This indicates, for example, that $2^{\circ} \mathrm{C}$ warm water present both near the surface and at about 200-m depth have salinity concentrations of about 30 and 33 psu (Fig. 8c), respectively.

Besides the spatiotemporal variability in runoff (including englacial and subglacial runoff coming across the grounding line driving an upward buoyant plume to the surface at the ice margin, suggesting enhanced vertical mixing near the glacier margin), the distribution of salinity in Ilulissat Icefjord is controlled by processes 

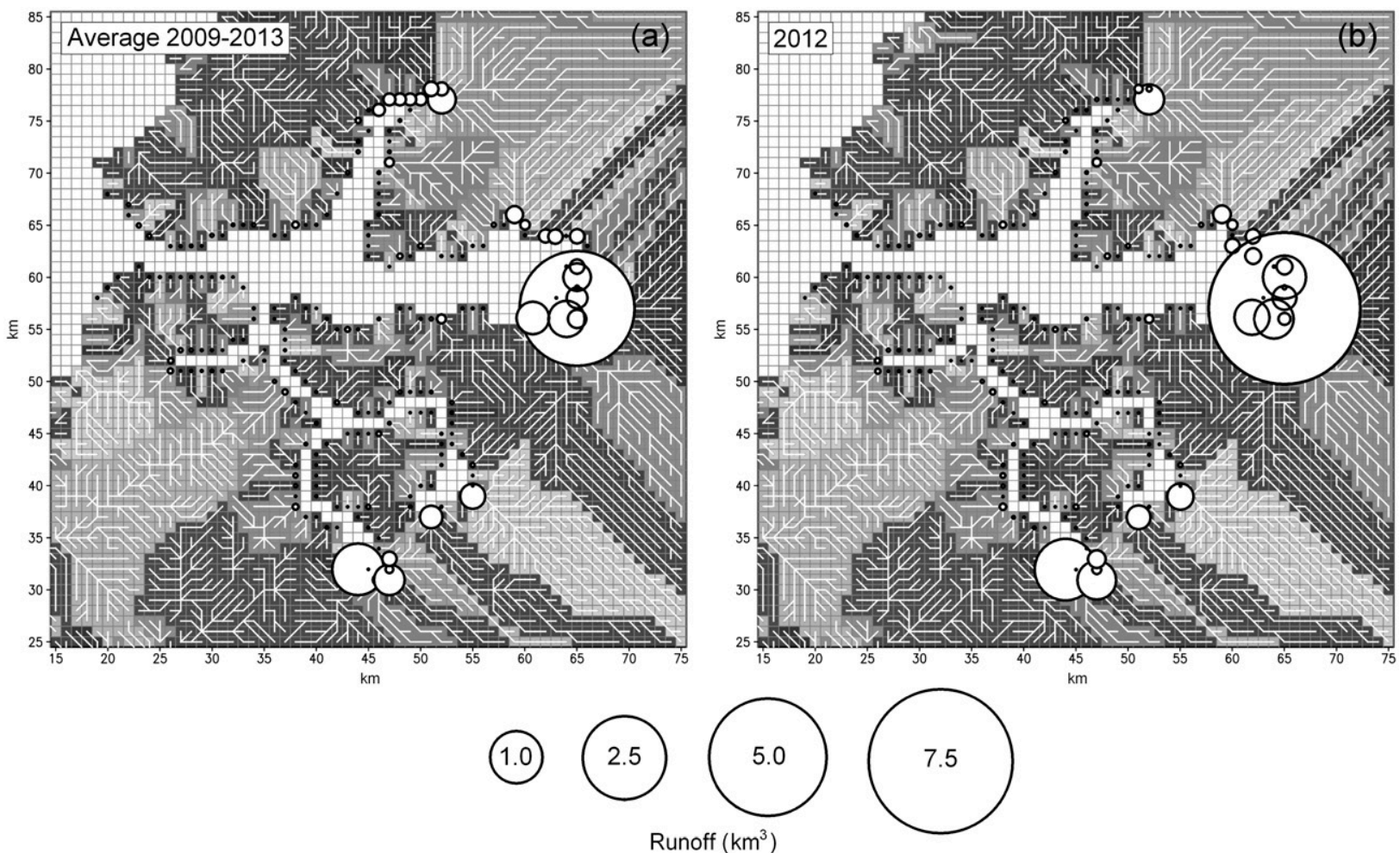

$\operatorname{Runoff}\left(\mathrm{km}^{3}\right)$
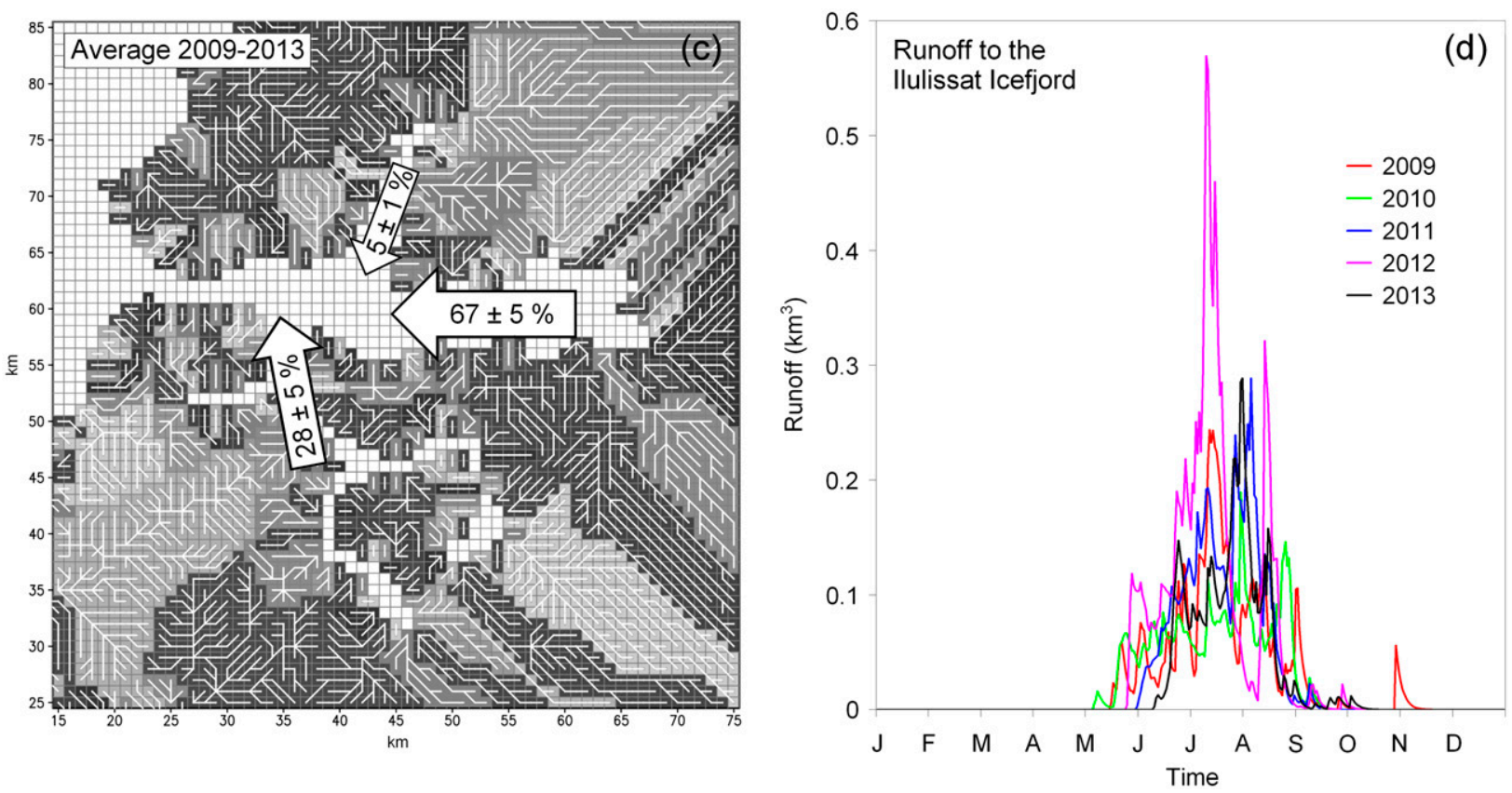

FIG. 6. Terrestrial spatial runoff distribution to the Ilulissat Icefjord estimated in HydroFlow: (a) mean annual values from 2009 to 2013 (the area of each circle is proportional to the runoff); (b) 2012; (c) relative mean runoff (and standard deviation) contributions to the northern and southern fjord arms and to the inner part of the fjord; and (d) time series of daily, modeled runoff hydrographs from 2009 to 2013.

such as the seasonal variability in calving (probably only minor because of the little seasonal variability in ice discharge from Jakobshavn Isbrae; Fig. 4), transit time of submarine melting icebergs floating through the fjord, weather variability (in wind speed, wind direction, and rain events), the tidal prism (the amount of water that flows into and out of the fjord, excluding any contribution from freshwater inflows), and exchanges with Disko 

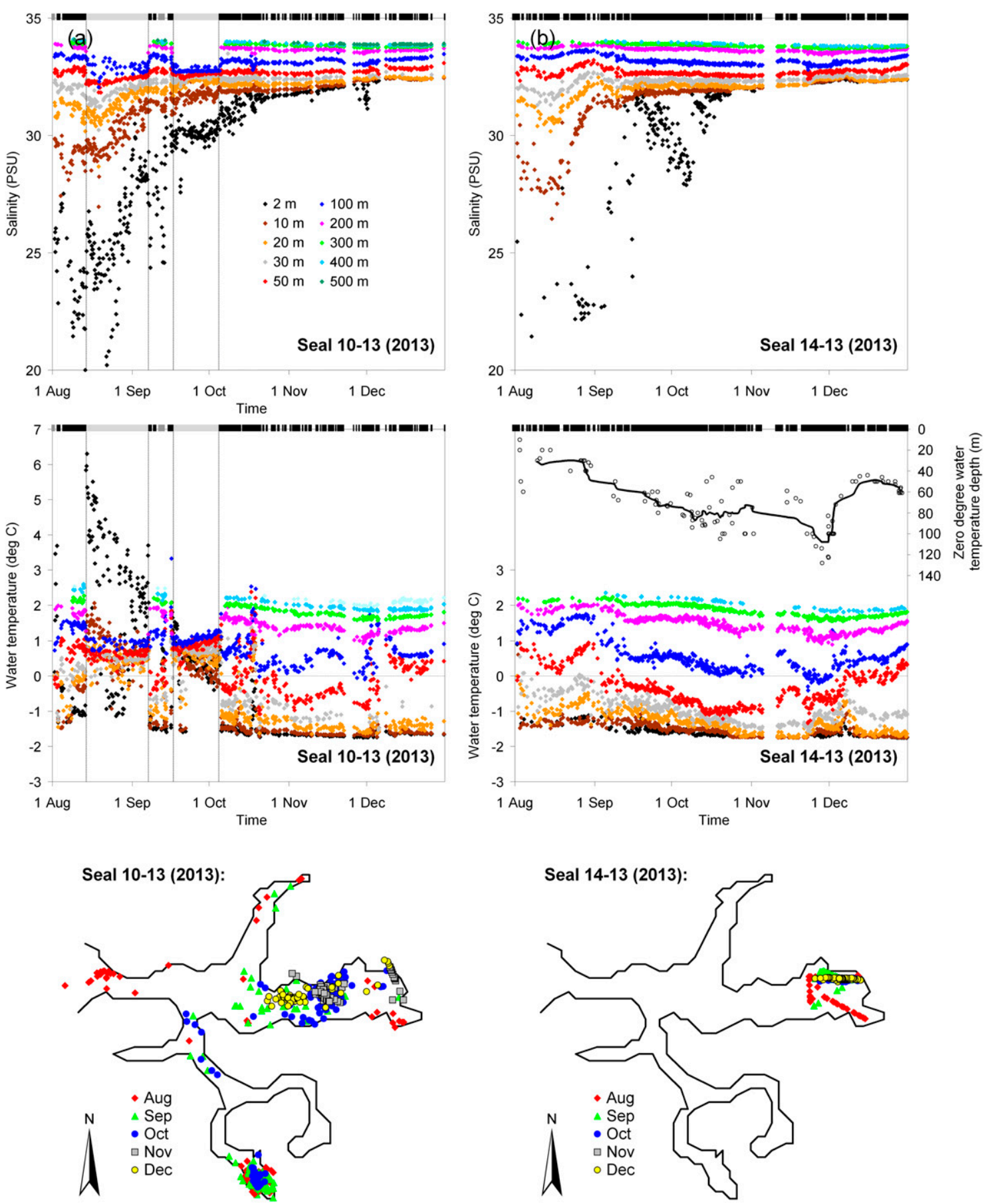

FIG. 7. Time series of observed salinity and water temperature from SRDL mounted to two ringed seals: (a) seal 10-13 and (b) seal 1413 in the Ilulissat Icefjord system from August to December 2013 at 2-, 10-, 20-, 30-, 50-, 100-, 200-, 300-, 400-, and 500-m depths. The seal positions are shown for the time series, for the northern arm (marked with dark gray at the top of the figures), for the main fjord (marked with black), and for the southern arm (marked with light gray). The period where the seal is in the southern arm is further highlighted with vertical dotted lines in (a). The geographical locations of the seals are categorized by month. In (b), the main Ilulissat Icefjord $0^{\circ}$ water temperature line (10-day running mean) is shown. 

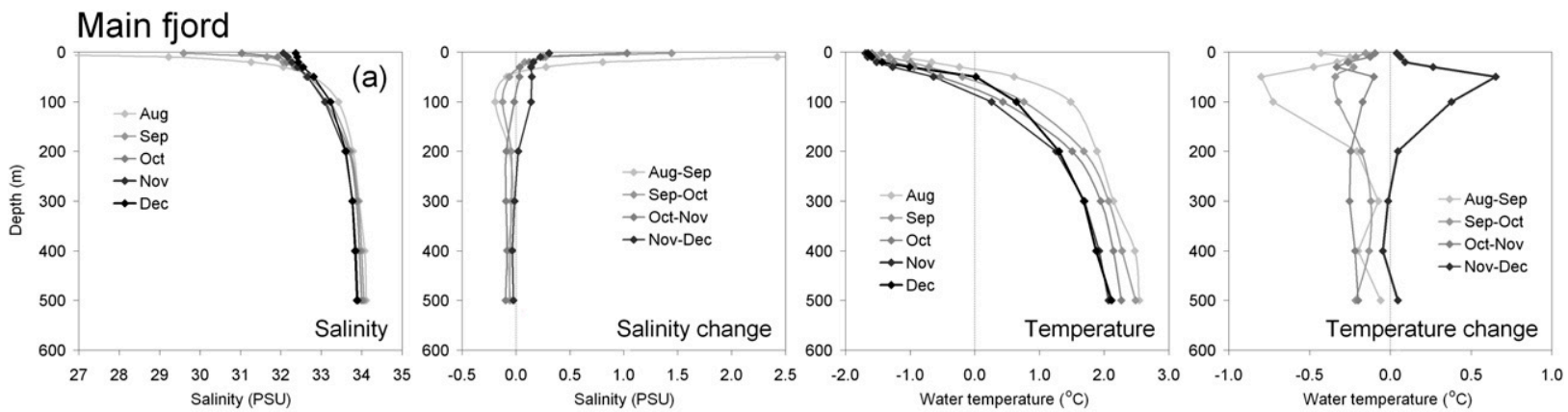

\section{Southern fjord arm}
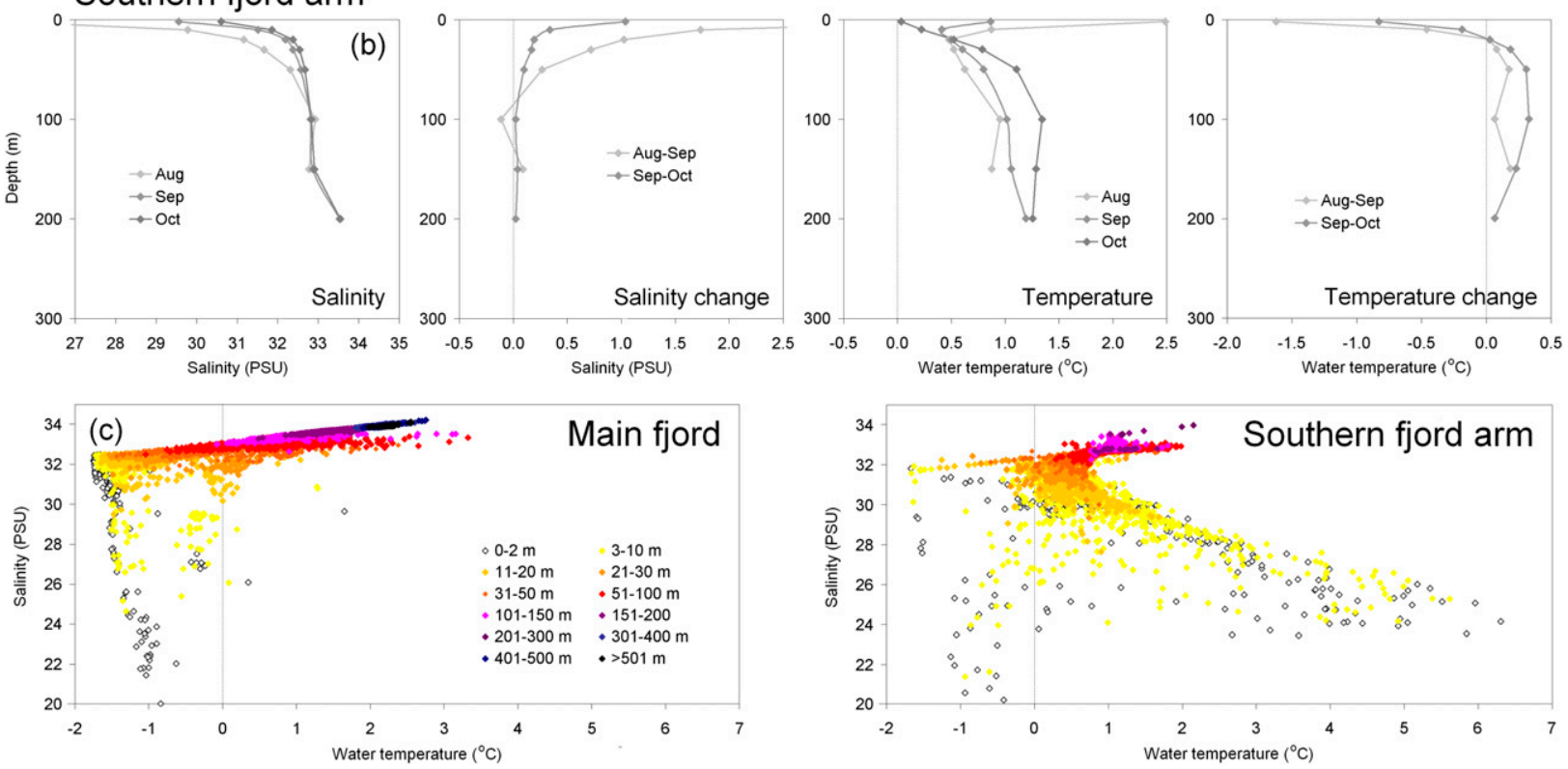

FIG. 8. Seal-observed salinity and water temperature conditions for the main fjord and southern fjord arm: (a) mean monthly salinity, salinity change, water temperature, and water temperature change depth profiles from August to December for the main fjord. (b) As in (a), but for the southern fjord arm. (c) $T-S$ profile for the main fjord and the southern fjord arm. Note different scales on the ordinate in (a) and (b).

Bay (inflow of ocean water at depth, complicated by a fjord sill at $\sim 250-\mathrm{m}$ depth at the mouth of the fjord, and outflow of a mixture of glacial meltwater and ocean water at the surface). In Fig. 9, linear correlations between runoff and salinity and temperature for both the main fjord and the southern fjord arm are shown. For both fjords, relatively high (significant) $r^{2}$ values (square of the linear correlation coefficient) of about 0.6 are present (explaining about $60 \%$ of the variability) in the near surface of the water column. Such stratification with fresh waters at the surface is typically consistent with terrestrial runoff and surface ice melt (Straneo et al. 2012). Further down the water column between 100- and 400-m depth, the $r^{2}$ value dropped to $0.1-0.2$ and increased below $400-\mathrm{m}$ depth to $r^{2}$ value of $0.3-0.4$ (Fig. 9). This indicates that variations in terrestrial runoff have lesser correlations with variations in hydrographic conditions (salinity and temperature) in the interval from 100 to $400 \mathrm{~m}$. Below $400 \mathrm{~m}$, the increase in $r^{2}$ value could be related to the mixing of meltwater moving upward from passing the grounding line.

\section{d. Salinity change near tidewater glacier margins after runoff spikes}

Runoff spikes occurred 1-2 August (total runoff on 1 August was $0.29 \mathrm{~km}^{3}$ for the entire catchment) and 2-6 September (2 September total runoff was $0.03 \mathrm{~km}^{3}$ ). This can be compared with daily total runoff amounts of $0.001-0.011 \mathrm{~km}^{3}$ during $19-30$ September when runoff was in recession. During these three specific time periods, seal 10-13 was either positioned at the head of the northern or southern fjords near the GrIS outlet margins (see inset map in Fig. 10a), and seal 14-13 was 
TABLE 5. Mean and standard deviation seal-observed salinity and water temperature at different depths for the main fjord and the southern fjord arm. Dashed lines are present where no data are available.

\begin{tabular}{|c|c|c|c|c|c|c|}
\hline & Depth (m) & August & September & October* & November & December \\
\hline \multirow{20}{*}{$\begin{array}{l}\text { Main fjord (seal 10-13 } \\
\text { and seal 14-13) }\end{array}$} & \multirow[t]{2}{*}{2} & $23.3 \pm 1.9$ & $29.6 \pm 2.0$ & $31.0 \pm 1.0$ & $32.1 \pm 0.2$ & $32.4 \pm 0.1$ \\
\hline & & $-1.0 \pm 0.4$ & $-1.4 \pm 0.4$ & $-1.6 \pm 0.1$ & $-1.7 \pm<0.1$ & $-1.7 \pm<0.1$ \\
\hline & \multirow[t]{2}{*}{10} & $29.2 \pm 1.5$ & $31.7 \pm 0.2$ & $31.9 \pm 0.1$ & $32.2 \pm 0.1$ & $32.4 \pm 0.1$ \\
\hline & & $-1.1 \pm 0.5$ & $-1.3 \pm 0.3$ & $-1.5 \pm 0.2$ & $-1.7 \pm 0.1$ & $-1.6 \pm 0.3$ \\
\hline & \multirow[t]{2}{*}{20} & $31.3 \pm 0.5$ & $32.3 \pm 0.1$ & $32.1 \pm 0.1$ & $32.3 \pm 0.1$ & $32.4 \pm 0.1$ \\
\hline & & $-0.7 \pm 0.4$ & $-1.0 \pm 0.3$ & $-1.3 \pm 0.3$ & $-1.5 \pm 0.1$ & $-1.4 \pm 0.3$ \\
\hline & \multirow[t]{2}{*}{30} & $32.1 \pm 0.3$ & $32.3 \pm 0.1$ & $32.4 \pm 0.1$ & $32.4 \pm 0.1$ & $32.6 \pm 0.1$ \\
\hline & & $-0.2 \pm 0.4$ & $-0.7 \pm 0.4$ & $-0.9 \pm 0.4$ & $-1.3 \pm 0.2$ & $-1.0 \pm 0.4$ \\
\hline & \multirow[t]{2}{*}{50} & $32.8 \pm 0.2$ & $32.7 \pm 0.1$ & $32.7 \pm 0.1$ & $32.7 \pm 0.1$ & $32.8 \pm 0.1$ \\
\hline & & $0.6 \pm 0.3$ & $-0.2 \pm 0.4$ & $-0.5 \pm 0.6$ & $-0.6 \pm 0.2$ & $0.0 \pm 0.4$ \\
\hline & \multirow[t]{2}{*}{100} & $33.4 \pm 0.1$ & $33.2 \pm 0.1$ & $33.1 \pm 0.1$ & $33.1 \pm 0.1$ & $33.2 \pm 0.1$ \\
\hline & & $1.5 \pm 0.2$ & $0.8 \pm 0.4$ & $0.4 \pm 0.4$ & $0.3 \pm 0.3$ & $0.6 \pm 0.3$ \\
\hline & \multirow[t]{2}{*}{200} & $33.8 \pm 0.1$ & $33.7 \pm 0.1$ & $33.7 \pm 0.1$ & $33.6 \pm 0.1$ & $33.6 \pm 0.1$ \\
\hline & & $1.9 \pm 0.1$ & $1.7 \pm 0.1$ & $1.5 \pm 0.1$ & $1.3 \pm 0.2$ & $1.3 \pm 0.1$ \\
\hline & \multirow[t]{2}{*}{300} & $33.9 \pm<0.1$ & $33.9 \pm<0.1$ & $33.9 \pm<0.1$ & $33.8 \pm<0.1$ & $33.8 \pm<0.1$ \\
\hline & & $2.1 \pm<0.1$ & $2.1 \pm<0.1$ & $1.9 \pm 0.1$ & $1.7 \pm 0.1$ & $1.7 \pm 0.1$ \\
\hline & \multirow[t]{2}{*}{400} & $34.0 \pm<0.1$ & $34.0 \pm<0.1$ & $33.9 \pm<0.1$ & $33.9 \pm<0.1$ & $33.8 \pm<0.1$ \\
\hline & & $2.5 \pm 0.1$ & $2.3 \pm 0.1$ & $2.1 \pm 0.1$ & $1.9 \pm 0.1$ & $1.9 \pm 0.1$ \\
\hline & \multirow[t]{2}{*}{500} & \multirow[t]{2}{*}{-} & $34.1 \pm<0.1$ & $34.0 \pm<0.1$ & $33.9 \pm<0.1$ & $33.9 \pm<0.1$ \\
\hline & & & $2.5 \pm 0.1$ & $2.3 \pm<0.1$ & $2.1 \pm 0.1$ & $2.1 \pm 0.1$ \\
\hline \multirow[t]{16}{*}{ Southern arm (Seal 10-13) } & \multirow[t]{2}{*}{2} & $25.2 \pm 1.7$ & $29.6 \pm 0.9$ & $30.6 \pm 0.5$ & - & - \\
\hline & & $2.5 \pm 2.1$ & $0.9 \pm 1.0$ & $0.0 \pm 0.7$ & & \\
\hline & \multirow[t]{2}{*}{10} & $29.8 \pm 0.7$ & $31.5 \pm 0.5$ & $31.9 \pm 0.2$ & - & - \\
\hline & & $0.9 \pm 0.6$ & $0.4 \pm 0.5$ & $0.2 \pm 0.5$ & & \\
\hline & \multirow[t]{2}{*}{20} & $31.2 \pm 0.5$ & $32.2 \pm 0.2$ & $32.4 \pm 0.1$ & - & - \\
\hline & & $0.5 \pm 0.3$ & $0.5 \pm 0.3$ & $0.5 \pm 0.4$ & & \\
\hline & \multirow[t]{2}{*}{30} & $31.7 \pm 0.4$ & $32.4 \pm 0.2$ & $32.5 \pm 0.1$ & - & - \\
\hline & & $0.5 \pm 0.2$ & $0.6 \pm 0.3$ & $0.8 \pm 0.3$ & & \\
\hline & \multirow[t]{2}{*}{50} & $32.3 \pm 0.2$ & $32.6 \pm 0.1$ & $32.7 \pm<0.1$ & - & - \\
\hline & & $0.6 \pm 0.1$ & $0.8 \pm 0.2$ & $1.1 \pm 0.3$ & & \\
\hline & \multirow[t]{2}{*}{100} & $32.7 \pm 0.3$ & $32.8 \pm 0.1$ & $32.8 \pm 0.1$ & - & - \\
\hline & & $0.9 \pm 0.1$ & $1.0 \pm 0.1$ & $1.3 \pm 0.3$ & & \\
\hline & \multirow[t]{2}{*}{150} & $32.8 \pm 0.4$ & $32.9 \pm 0.2$ & $32.9 \pm 0.2$ & - & - \\
\hline & & $0.9 \pm 0.2$ & $1.1 \pm 0.1$ & $1.3 \pm 0.2$ & \multirow{3}{*}{-} & \multirow{3}{*}{-} \\
\hline & \multirow[t]{2}{*}{200} & \multirow[t]{2}{*}{-} & $33.4 \pm<0.1$ & $33.5 \pm 0.1$ & & \\
\hline & & & $1.2 \pm<0.1$ & $1.3 \pm 0.2$ & & \\
\hline
\end{tabular}

* For the Southern arm, the observed seal 10-13 data for August and October covers the period from 18 to 31 Aug and 1 to 18 Oct, respectively.

positioned either at the head of the northern fjord or near the Jakobshavn Isbrae (see inset map in Fig. 10b) (during other simulated runoff spikes the seals were not located nearby any tidewater glacier margins). For the two periods with simulated spike runoff, for example, the salinity profiles near the tidewater glacier margins vary from $\sim 25$ (at $2-\mathrm{m}$ depth) to $33 \mathrm{psu}$ (at $150 \mathrm{~m}$ ) for the northern arm, and $\sim 29(2 \mathrm{~m})$ to $33 \mathrm{psu}(100 \mathrm{~m})$ for the southern arm (Figs. 10a,b). However, for the southern arm an increase in salinity at $100-150 \mathrm{~m}$ of up to $\sim 0.05-007 \mathrm{psu} \mathrm{m}^{-1}$ increasing depth is seen in $25 \%$ of the profiles (Fig. 10a). For comparison, the observed salinity between 50 and $100 \mathrm{~m}$ increased on average $\sim 0.01$ psu m $^{-1}$ with increasing depth. As this increase in salinity (at 100-150 m) is only seen in one-fourth of the salinity profiles, it seems possible that meltwater is concentrated at some locations near the ice front and absent at others. At the glacier front, the heterogeneous salinity distribution (at 100-150 m) could be because of the mixing of meltwater moving upward from the grounding line. Further, during periods of several days after a runoff spike, there were changes in salinity in the upper $50 \mathrm{~m}$ of the water column of about $-0.5 \mathrm{psu}$ in the northern arm and between about -1.0 and $1.2 \mathrm{psu}$ in the southern arm (Fig. 10). The change in salinity became smaller with increasing depth to a level in 150(in the northern arm) and 100-m depth (southern arm), where salinity changes fell below the accuracy of the measurements (Figs. 10a,b).

The vertically uneven change in salinity in days after a runoff spike could indicate uneven vertical distribution of runoff draining through the glacier margin. In this 

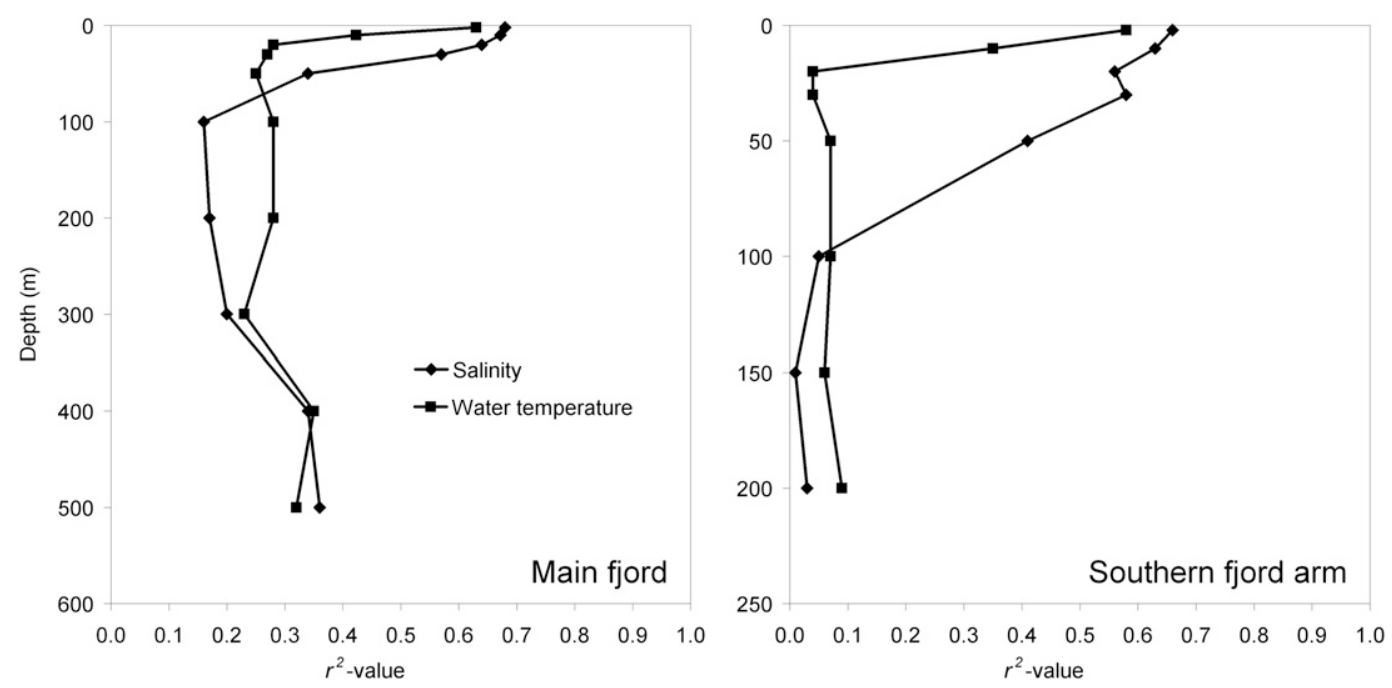

FIG. 9. (a) Main fjord and (b) southern fjord arm depth profiles of $r^{2}$ values estimated between simulated runoff and seal-observed salinity and simulated runoff and seal-observed water temperature at 2-, 10-, 20-, 30-, 50-, 100-, 150-, 200-, 300-, 400-, and 500-m depths. Note the different scales on the ordinate.

case, it shows that most runoff entered the fjord near the surface and in the upper $50 \mathrm{~m}$ [the amount of englacial runoff decreased from the water surface and downward (Figs. 10a,b)]. The seal dive profiles did not capture any signal of englacial freshwater entering the fjord across the grounding line. The reason, however, could be that the seals did not dive deep enough (or close enough to the ice margins) near the grounding line. Even in the relatively shallower north and south arms, the sealborne instruments only obtained salinity observations in the upper $\sim 150$ (north arm) or $100 \mathrm{~m}$ (south arm) of the water column, while the bottoms of the fjord and the grounding line are expected to be at depths of about 500 (north arm) and $150 \mathrm{~m}$ (south arm).

The salinity change profiles in days after a runoff peak are most pronounced near the glacier margin in both the northern and southern fjords, where the calving rates are relatively low (only a minor production of icebergs has been observed). Therefore, variability in runoff is likely to constitute an important role in salinity changes near those glacier margins. Changes in the salinity stratification recorded by seal 14-13 near Jakobshavn Isbrae for the period 2-6 September seem less pronounced compared to salinity observations near glacier margins in the two fjord arms. This is probably because of the amount of runoff, and subsequently the ratio between runoff and calving, as the runoff volume and changes in runoff only have a minor effect on the overall freshwater flux from the Jakobshavn Isbrae catchment (Table 4). In other words, the melting of calved icebergs may determine near-surface salinities in the main fjord more than runoff, which seems to be opposite the conditions in the northern and southern fjords, where the calving rates are relatively low.

For the period 19-30 September, during a period of falling runoff (and where seal 10-13 was close to the ice margin in the southern fjord and seal 14-13 close to Jakobshavn Isbrae), no systematic changes in salinity occurred from one day to another in the upper $150 \mathrm{~m}$ of the water column showing both increasing and decreasing changes (Figs. 10a,b). Below 100-150-m water depth, changes in salinity were on average within the salinity accuracy. These 19-30 September salinity observations support the statement that runoff variability coming through the englacial drainage system entering the fjord may influence the near-surface and upper water column salinity conditions, most pronounced at the fjords arms where ice discharge is less significant.

\section{Summary}

The freshwater flux to Ilulissat Icefjord is estimated based on contributions from ice discharge from Jakobshavn Isbrae, from simulated runoff, from precipitation at the fjord surface area, from subglacial geothermal melting, and from frictional melting due to basal ice motion. For the period 2009-13, the mean freshwater flux from land was $70.6 \pm 4.2 \mathrm{~km}^{3}$, where $85 \%$ came from ice discharge (from Jakobshavn Isbrae), $14 \%$ came from runoff, and $1 \%$ came from precipitation, subglacial geothermal melting, and frictional melting due to basal ice motion. On a monthly scale, the mean monthly ice discharge varies from minimum 

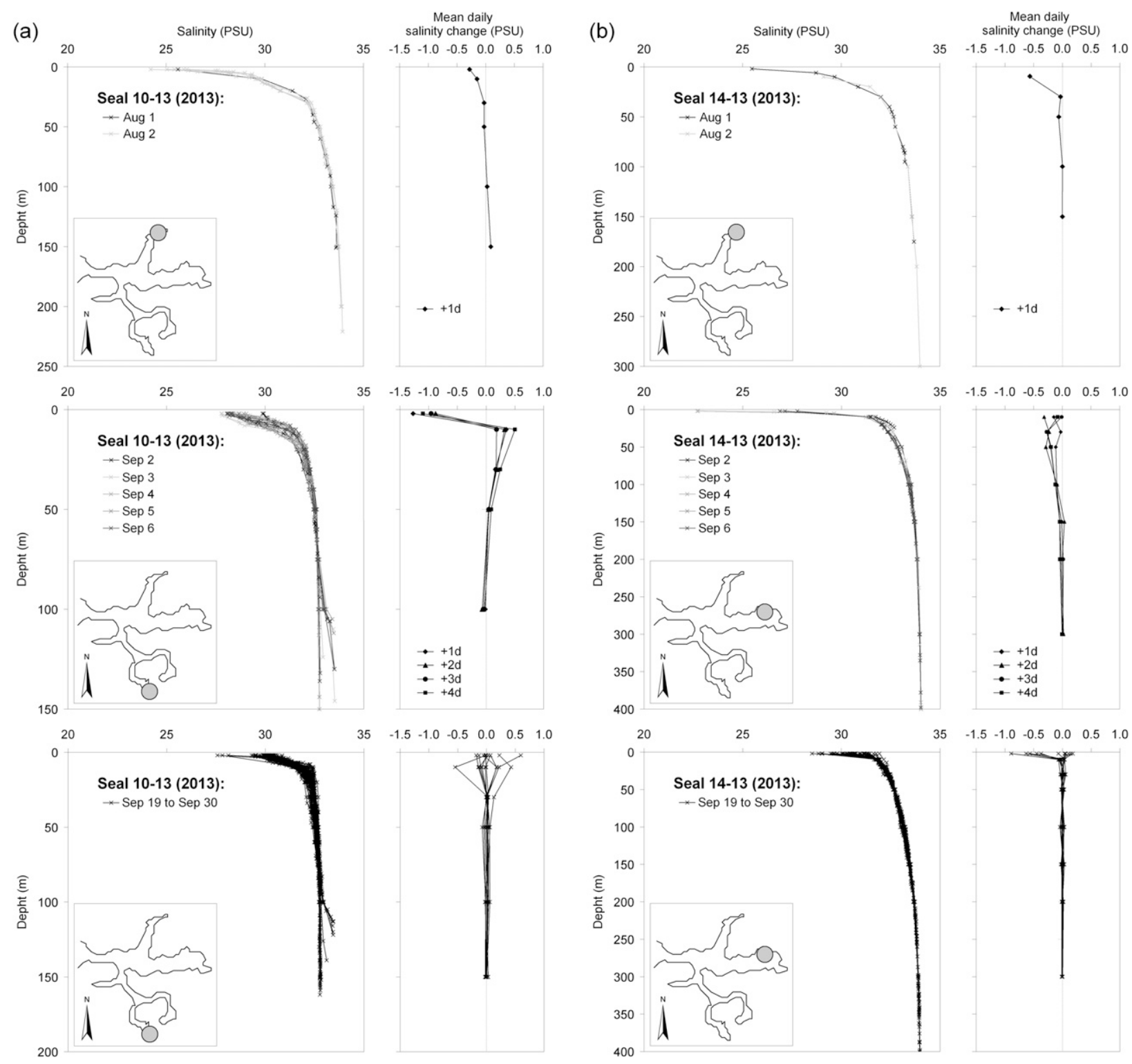

FIG. 10. Vertical salinity profiles observed from SRDL mounted to two ringed seals: (a) seal 10-13 and (b) seal 14-13 in the Ilulissat Icefjord system in 2013. Salinity profiles during the two periods 1-2 Aug and 2-6 Sep were observed right after a peak in simulated runoff and when the seals were near the GrIS outlet glaciers. Salinity profiles are shown for the period 19-30 Sep, where the seals were near the GrIS outlet glaciers and a simulated runoff recession occurred. The inset maps indicate the general location of the seals in the Ilulissat Icefjord system, marked with a gray dot.

$4.50 \pm 0.05 \mathrm{~km}^{3}$ in December to a maximum of $4.95 \pm$ $0.11 \mathrm{~km}^{3}$ in July, while runoff varies from zero (no runoff) in October through April to $2.47 \pm 0.67 \mathrm{~km}^{3}$ in July. For July and August, for example, the Jakobshavn Isbrae catchment runoff was simulated to be $50 \%$ and $34 \%$ of the monthly ice discharge coming from Jakobshavn Isbrae, respectively, and $91 \%$ and $55 \%$ for the overall Ilulissat Icefjord runoff, respectively. The simulated freshwater contributions from terrestrial runoff to Ilulissat Icefjord are, however, controlled by the combined effect of climate impacts from temperature (snow and ice melt) and precipitation (rain and snow) and impacts from the characteristics of the landscape due to runoff flow, storage, and transit times. The displayed connection between terrestrial modeled spatiotemporal runoff and changes in seal-obtained observations of Ilulissat Icefjord salinity and temperature shows how nearsurface salinities and temperatures in the Ilulissat Icefjord and near ice margins is likely to change over a runoff season due to variability in runoff and iceberg melting. 
Different hydrographic conditions are present between the main fjord and the southern fjord arm. During months with relatively high runoff and ice discharge, the salinity in the upper part (upper $\sim 25 \mathrm{~m}$ ) of the water column was relatively low (around 23-32 psu), indicating a freshwater surface cap. Throughout the observation period at depths of about $200 \mathrm{~m}$, salinities were much more homogeneous.

In the north and south arms of Ilulissat Icefjord, salinity changes in the upper water column are significant after temporal spikes in runoff during late summer, while small-amplitude runoff variability during the recession of runoff in late summer does not create a clear signal. The effect of runoff spikes on fjord salinity is, however, less pronounced near the ice margin of Jakobshavn Isbrae than in the north and south arms. Also, for the main fjord and southern arm, high correlations (explaining $60 \%$ of the variability) were observed between runoff and salinity and temperature in the upper part of the water column. Between 100- and 400-m depth the correlation dropped and rose again below 400-m depth, probably related to mixing of meltwater going upward from passing the grounding line. A detailed understanding of the processes and connections between englacial and subglacial runoff and calving, changes in hydrographic conditions, and subsequently the impact on ice-ocean interactions is important to our understanding of present-day conditions of frontal retreat, speedup, and dynamic thinning of marine-terminating glaciers, including Jakobshavn Isbrae and model projections of future changes.

Acknowledgments. We thank the two anonymous reviewers for their valuable comments. We thank the Danish Meteorological Institute, Greenland Climate Network (GC-Net), and New York University for providing meteorological data for this study. Ian Joughin is acknowledged for providing information about the satellite-derived locations of the Jakobshavn Isbrae terminus in mid/late summer 2009-13. The beginning of this work came out of two visits to New York University [February 2011 (2 weeks) and January 2012 (1 week)], supported by the Earth System Modeling program of the Office of Biological and Environmental Research within the U.S. Department of Energy's Office of Science, while S.H.M. was working at Los Alamos National Laboratory. Otherwise, this study has been funded entirely by New York University and New York University Abu Dhabi under the Center for Global Sea-Level Change (CSLC) Grant G1204. Request of spatiotemporal simulated runoff data should be addressed to the first author.

\section{REFERENCES}

Allerup, P., H. Madsen, and F. Vejen, 1998: Estimating true precipitation in Arctic areas. Proc. Nordic Hydrological Conference, Nordic Hydrological Programme Rep. 44, Helsinki, Finland, Nordic Hydrological Programme, 1-9.

,-- , and — 2000: Correction of precipitation based on off-site weather information. Atmos. Res., 53, 231-250, doi:10.1016/S0169-8095(99)00051-4.

Amundson, J. M., M. Fahnestock, M. Truffer, J. Brown, M. P. Luthi, and R. J. Motyka, 2010: Ice mélange dynamics and implications for terminus stability, Jakobshavn Isbrae, Greenland. J. Geophys. Res., 115, F01005, doi:10.1029/ 2009JF001405.

Bamber, J., M. J. van den Broeke, J. Ettema, J. Lenaerts, and E. Rignot, 2012: Recent large increases in freshwater fluxes from Greenland into the North Atlantic. Geophys. Res. Lett., 39, L19501, doi:10.1029/2012GL052552.

Born, E. W., and J. Bocher, 2001: The Ecology of Greenland. Atuakkiorfik Education, 429 pp.

Box, J. E., and D. T. Decker, 2011: Greenland marine-terminating glacier area changes: 2000-2010. Ann. Glaciol., 52, 91-98, doi:10.3189/172756411799096312.

— Update for 2012, NOAA, 146-158. [Available online at www. arctic.noaa.gov/report12/ArcticReportCard_full_report.pdf.]

Enderlin, E. M., I. M. Howat, S. Jeong, M.-J. Hoh, J. H. van Angelen, and M. R. van den Broeke, 2014: An improved mass budget for the Greenland Ice Sheet. Geophys. Res. Lett., 41, 866-872, doi:10.1002/2013GL059010.

Gladish, C., D. Holland, A. Rosing-Asvid, J. Behrens, and J. Boje, 2015: Oceanic boundary conditions for Jakobshavn Glacier. Part I: Variability and renewal of Ilulissat Icefjord Waters, 2001-14. J. Phys. Oceanogr., 45, 3-32, doi:10.1175/ JPO-D-14-0044.1.

Goodison, B. E., B. Sevruk, and S. Klemm, 1989: WMO solid precipitation measurement intercomparison: Objectives, methodology, analysis. IAHS Publ., 179, 57-64.

Hanna, E., J. Cappelen, X. Fettweis, P. Huybrechts, A. Luckman, and M. H. Ribergaard, 2009: Hydrologic response of the Greenland Ice Sheet: The role of oceanographic forcing. Hydrol. Processes, 23, 7-30, doi:10.1002/ hyp.7090.

, S. H. Mernild, J. Cappelen, and K. Steffen, 2012: Recent warming in Greenland in a long-term instrumental (18812012) climatic context: I. Evaluation of surface air temperature records. Environ. Res. Lett., 7, 045404, doi:10.1088/ 1748-9326/7/4/045404.

— J. M. Jones, J. Cappelen, S. H. Mernild, L. Wood, K. Steffen, and P. Huybrechts, 2013a: The influence of North Atlantic atmospheric and oceanic forcing effects on 1900-2010 Greenland summer climate and icemelt/runoff. Int. J. Climatol., 33, 862-880, doi:10.1002/joc.3475.

, and Coauthors, 2013b: Atmospheric and oceanic climate forcing of the exceptional Greenland Ice Sheet surface melt in summer 2012. Int. J. Climatol., 34, 1022-1037, doi:10.1002/ joc.3743.

Hansen, M., T. Nielsen, C. Stedmon, and P. Munk, 2012: Oceanographic regime shift during 1997 in Disko Bay, western Greenland. Limnol. Oceanogr., 57, 634-644, doi:10.4319/ lo.2012.57.2.0634.

Hasholt, B., and Coauthors, 2008: Hydrology and transport of sediment and solutes at Zackenberg. High-Arctic Ecosystem 
Dynamics in a Changing Climate, H. Meltofte et al., Eds., Advances in Ecological Research, Vol. 40, Elsevier, 111-149. Holland, D. M., R. H. Thomas, B. de Young, M. H. Ribergaard, and B. Lyberth, 2008: Acceleration of Jakobshavn Isbræ triggered by warm subsurface ocean waters. Nat. Geosci., 1, 659-664, doi:10.1038/ngeo316.

Howat, I. M., and A. Eddy, 2011: Multi-decadal retreat of Greenland's marine-terminating glaciers. J. Glaciol., 57, 389396, doi:10.3189/002214311796905631.

—, I. Joughin, and T. A. Scambos, 2007: Rapid changes in ice discharge from Greenland outlet glaciers. Science, 315, 15591561, doi:10.1126/science.1138478.

—, Y. Ahn, I. Joughin, M. R. van den Broeke, J. T. M. Lenaerts, and B. Smith, 2011: Mass balance of Greenland's three largest outlet glaciers, 2000-2010. Geophys. Res. Lett., 38, L12501, doi:10.1029/2011GL047565.

— A. Negrete, and B. E. Smith, 2014: The Greenland Ice Mapping Project (GIMP) land classification and surface elevation datasets. Cryosphere Discuss., 8, 453-478, doi:10.5194/ tcd-8-453-2014.

Joughin, I., B. E. Smith, I. M. Howat, T. Scamboc, and T. Moon, 2010: Greenland flow variability from ice-sheet-wide velocity mapping. J. Glaciol., 56, 415-430, doi:10.3189/002214310792447734.

_ R. B. Alley, and D. M. Holland, 2012: Ice-sheet response to oceanic forcing. Science, 338, 1172-1176, doi:10.1126/ science. 1226481.

— B. E. Smith, D. E. Shean, and D. Floricioiu, 2014: Further summer speedup of Jakobshavn Isbræ. Cryosphere, 8, 209214, doi:10.5194/tc-8-209-2014.

Khan, S. A., and Coauthors, 2014: Sustained mass loss of the northeast Greenland Ice Sheet trigged by regional warming. Nat. Climate Change, 4, 292-299, doi:10.1038/nclimate2161.

Liston, G. E., 1995: Local advection of momentum, heat, and moisture during the melt of patchy snow covers. J. Appl. Meteor., 34, 1705-1715, doi:10.1175/1520-0450-34.7.1705.

—_, and D. K. Hall, 1995: An energy-balance model of lake-ice evolution. J. Glaciol., 41, 373-382.

— terrain. J. Glaciol., 44, 498-516.

—, and —, 2002: Winter precipitation patterns in Arctic Alaska determined from a blowing-snow model and snowdepth observations. J. Hydrometeor., 3, 646-659, doi:10.1175/ 1525-7541(2002)003<0646:WPPIAA $>2.0$.CO;2.

— eling system (SnowModel). J. Hydrometeor., 7, 1259-1276, doi:10.1175/JHM548.1.

—_, and —_, 2006b: A meteorological distribution system for high-resolution terrestrial modeling (MicroMet). J. Hydrometeor., 7, 217-234, doi:10.1175/JHM486.1.

— Arctic snow trends (1979-2009). J. Climate, 24, 5691-5712, doi:10.1175/JCLI-D-11-00081.1.

— A runoff routing model for glaciated and non-glaciated landscapes (HydroFlow). J. Climate, 25, 5997-6014, doi:10.1175/ JCLI-D-11-00591.1.

_- J.-G. Winther, O. Bruland, H. Elvehøy, and K. Sand, 1999: Below-surface ice melt on the coastal Antarctic Ice Sheet. J. Glaciol., 45, 273-285, doi:10.3189/002214399793377130.

—, R. B. Haehnel, M. Sturm, C. A. Hiemstra, S. Berezovskaya, and R. D. Tabler, 2007: Simulating complex snow distributions in windy environments using SnowTran-3D. J. Glaciol., 53, 241-256, doi:10.3189/172756507782202865.
Luckman, A., and T. Murray, 2005: Seasonal variations in velocity before retreat of Jakobshavn Isbrae, Greenland. Geophys. Res. Lett., 32, L08501, doi:10.1029/2005GL022519.

,,-- R. de Lange, and E. Hanna, 2006: Rapid and synchronous ice-dynamic charges in east Greenland. Geophys. Res. Lett., 33, L03503, doi:10.1029/2005GL025428.

McGrath, D., W. Colgan, N. Bayou, A. Muto, and K. Steffen, 2013: Recent warming at Summit, Greenland: Global context and implications. Geophys. Res. Lett., 40, 2091-2096, doi:10.1002/ grl.50456.

Mernild, S. H., and B. Hasholt, 2006: Climatic control on river discharge simulations, Mittivakkat Glacier catchment, Ammassalik Island, SE Greenland. Nord. Hydrol., 37 (4-5), 327-346, doi:10.2166/nh.2006.018.

— inversion on snow melt and glacier surface mass-balance simulations, Ammassalik Island, southeast Greenland. J. Appl. Meteor. Climatol., 49, 47-67, doi:10.1175/ 2009JAMC2065.1.

— tribution and trends, 1960-2010. J. Climate, 25, 6015-6035, doi:10.1175/JCLI-D-11-00592.1.

,,-- B. Hasholt, and N. T. Knudsen, 2006: Snow distribution and melt modeling for Mittivakkat Glacier, Ammassalik Island, southeast Greenland. J. Hydrometeor., 7, 808-824, doi:10.1175/JHM522.1.

,$- \ldots$, and ——, 2007: Snow-distribution and melt modeling for glaciers in Zackenberg River drainage basin, north-eastern Greenland. Hydrol. Processes, 21, 3249-3263, doi:10.1002/ hyp. 6500 .

_ B. Hasholt, and G. E. Liston, 2008a: Climatic control on river discharge simulations, Zackenberg River drainage basin, northeast Greenland. Hydrol. Processes, 22, 1932-1948, doi:10.1002/hyp.6777.

_ D. L. Kane, B. U. Hansen, B. H. Jakobsen, B. Hasholt, and N. T. Knudsen, 2008b: Climate, glacier mass balance, and runoff (1993-2005) for the Mittivakkat Glacier catchment, Ammassalik Island, SE Greenland, and in a long term perspective (1898-1993). Hydrol. Res., 39 (4), 239-256, doi:10.2166/nh.2008.101.

— G. E. Liston, C. A. Hiemstra, and K. Steffen, 2008c: Surface melt area and water balance modeling on the Greenland Ice Sheet 1995-2005. J. Hydrometeor., 9, 1191-1211, doi:10.1175/ 2008JHM957.1.

,,--- , and,- 2009 : Greenland Ice Sheet surface mass-balance modelling and freshwater flux for 2007, and in a 1995-2007 perspective. Hydrol. Processes, 23, 2470-2484, doi:10.1002/hyp.7354.

_- and Coauthors, 2010a: Freshwater flux to Sermilik Fjord, SE Greenland. Cryosphere, 4, 453-465, doi:10.5194/tc-4-453-2010.

— G. E. Liston, C. A. Hiemstra, and J. H. Christensen, 2010b: Greenland Ice Sheet surface mass-balance modeling in a 131-yr perspective 1950-2080. J. Hydrometeor., 11, 3-25, doi:10.1175/2009JHM1140.1.

,,-- K. Steffen, and P. Chylek, 2010c: Meltwater flux and runoff modeling in the ablation area of the Jakobshavn Isbræ, west Greenland. J. Glaciol., 56, 20-32, doi:10.3189/ 002214310791190794.

,-- C. A. Hiemstra, J. H. Christensen, M. Stendel, and B. Hasholt, 2011a: Surface mass-balance and runoff modeling using HIRHAM4 RCM at Kangerlussuaq (Søndre Strømfjord), west Greenland, 1950-2080. J. Climate, 24, 609623, doi:10.1175/2010JCLI3560.1. 
T. Mote, and G. E. Liston, 2011b: Greenland Ice Sheet surface melt extent and trends, 1960-2010. J. Glaciol., 57, 621628, doi:10.3189/002214311797409712.

_ - E. Hanna, J. C. Yde, J. Cappelen, and J. K. Malmros, 2014: Coastal Greenland air temperature extremes and trends 1890 2010: Annual and monthly analysis. Int. J. Climatol., 34, 14721487, doi:10.1002/joc.3777.

,-- J. R. McConnell, M. Sigl, A. P. Beckerman, J. C. Yde, J. Cappelen, and K. Steffen, 2015: Greenland precipitation trends in a long-term instrumental climate context (1890 2012): Evaluation of coastal and ice core records. Int. J. Climatol., 35, 303-320, doi:10.1002/joc.3986.

Metcalfe, J. R., S. Ishida, and B. E. Goodison, 1994: A corrected precipitation archive for the Northwest Territories of Canada. [Available online at www.usask.ca/geography/MAGS/Data/ Public_Data/precip_corr/pcpncor_e.htm.]

Mikkelsen, A. B., B. Hasholt, N. T. Knudsen, and M. H. Nielsen, 2013: Jökulhlaups and sediment transport in Watson River, Kangerlussuaq, west Greenland. Hydrol. Res., 44, 58-67, doi:10.2166/nh.2012.165.

Motyka, R. J., M. Truffer, M. Fahnestock, J. Mortensen, S. Rysgaard, and I. Howat, 2011: Submarine melting of the 1985 Jakobshavn Isbræ floating tongue and the triggering of the current retreat. J. Geophys. Res., 116, F01007, doi:10.1029/ 2009JF001632.

Rahmstorf, and Coauthors, 2005: Thermohaline circulation hysteresis: A model intercomparison. Geophys. Res. Lett., 32, L23605, doi:10.1029/2005GL023655.

Rasmussen, R., and Coauthors, 2012: How well are we measuring snow: The NOAA/FAA/NCAR winter precipitation test bed. Bull. Amer. Meteor. Soc., 93, 811-829, doi:10.1175/ BAMS-D-11-00052.1.

Rennermalm, A. K., L. C. Smith, V. W. Chu, J. E. Box, R. R. Forster, M. R. van den Broeke, D. van As, and S. E. Moustafa, 2013: Evidence of meltwater retention within the Greenland Ice Sheet. Cryosphere, 7, 1433-1455, doi:10.5194/tc-7-1433-2013.

Rignot, E., and P. Kanagaratnam, 2006: Changes in the velocity structure of the Greenland Ice Sheet. Science, 311, 986-990, doi:10.1126/science.1121381.

_ I. Fenty, D. Menemenlis, and Y. Xu, 2012: Spreading of warm ocean waters around Greenland as a possible cause for glacier acceleration. Ann. Glaciol., 53 (60), 257-266, doi:10.3189/ 2012AoG60A136.
Steffen, K., 1995: Surface energy exchange at the equilibrium line on the Greenland Ice Sheet during onset of melt. Ann. Glaciol., 21, 13-18.

—, and J. E. Box, 2001: Surface climatology of the Greenland Ice Sheet: Greenland Climate Network 19951999. J. Geophys. Res., 106, 33 951-33 964, doi:10.1029/ 2001JD900161.

Straneo, F., G. S. Hamilton, D. A. Sutherland, L. A. Stearns, F. Davidson, M. O. Hammill, G. B. Stenson, and A. RosingAsvid, 2010: Rapid circulation of warm subtropical waters in a major glacial fjord in east Greenland. Nat. Geosci., 3, 182-186, doi:10.1038/ngeo764.

- R. G. Curry, D. A. Sutherland, G. S. Hamilton, C. Cenedese, K. Våge, and L. A. Sterns, 2011: Impact of fjord dynamics and glacial runoff on the circulation near Helheim Glacier. Nat. Geosci., 4, 322-327, doi:10.1038/ngeo1109.

_ , and Coauthors, 2012: Characteristics of ocean waters reaching Greenland's glaciers. Ann. Glaciol., 53 (60), 202-210, doi:10.3189/2012AoG60A059.

- , and Coauthors, 2013: Challenges to understanding the dynamic response of Greenland's marine terminating glaciers to oceanic and atmospheric forcing. Bull. Amer. Meteor. Soc., 94, 1131-1144, doi:10.1175/BAMS-D-12-00100.1.

Sutherland, D. A., F. Straneo, G. B. Stenson, F. J. M. Davidson, M. O. Hammill, and A. Rosing-Asvid, 2013: Atlantic water variability on the SE Greenland continental shelf and its relationship to SST and bathymetry. J. Geophys. Res. Oceans, 118, 847-855, doi:10.1029/2012JC008354.

Tedesco, M., and Coauthors, 2013: Greenland Ice Sheet. Arctic Report Card: Update for 2014, NOAA, 22-31. [Available online at www.arctic.noaa.gov/reportcard/ArcticReportCard_ full_report.pdf.]

Thomas, R. H., 2004: Force-perturbation analysis of recent thinning and acceleration of Jakobshavn Isbræ, Greenland. J. Glaciol., 50, 57-66, doi:10.3189/172756504781830321.

van den Broeke, M. J., and Coauthors, 2009: Partitioning recent Greenland mass loss. Science, 326, 984-986, doi:10.1126/ science. 1178176.

Weijer, W., M. E. Maltrud, M. W. Hecht, H. A. Dijkstra, and M. A. Kliphuis, 2012: Response of the Atlantic Ocean circulation to Greenland Ice Sheet melting in a strongly-eddying ocean model. Geophys. Res. Lett., 39, L09606, doi:10.1029/ 2012GL051611. 
Copyright of Journal of Physical Oceanography is the property of American Meteorological Society and its content may not be copied or emailed to multiple sites or posted to a listserv without the copyright holder's express written permission. However, users may print, download, or email articles for individual use. 